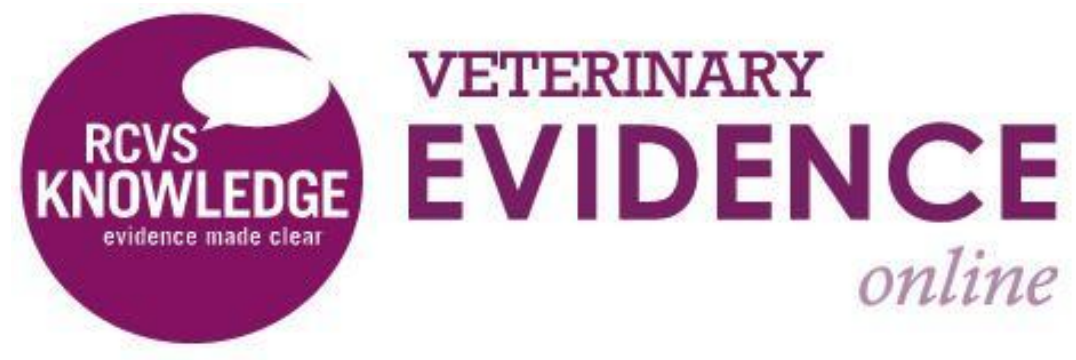

\title{
The Evidence Behind the Treatment of Canine Idiopathic Epilepsy
}

\section{A Knowledge Summary by}

Marios Charalambous DVM GPCert(Neuro) RSciMRSB MRCVS ${ }^{1 *}$ David Brodbelt MA VetMB PhD DVA DipECVAA MRCVS ${ }^{2}$ Holger Volk DVM PhD DipECVN FHEA MRCVS ${ }^{2}$

\footnotetext{
${ }^{1}$ University College London

${ }^{2}$ Royal Veterinary College

* Corresponding Author (marios.charalambous.15@ucl.ac.uk)
}

ISSN: 2396-9776

Published: 11 Feb 2016

in: Vol1, Issue 1

DOI: http://dx.doi.org/10.18849/ve.v1i1.9 


\section{Clinical bottom line}

Oral phenobarbital and imepitoin in particular, followed by potassium bromide and levetiracetam are likely to be effective for the treatment of canine idiopathic epilepsy. There is strong evidence supporting the use of oral phenobarbital and imepitoin as 'first line' medications. However, there remains a lack of evidence for targeted treatment for the various individual epileptic phenotypes and quite limited evidence on direct comparisons of the efficacy between various anti-epileptic drugs.

\section{Question}

In dogs with epilepsy, what is the best treatment to reduce seizures.

\section{Clinical scenario}

A 5 years old $17 \mathrm{~kg}$ German Shepherd intact male dog manifested generalized tonic-clonic seizures one year ago. In the last two months the dog manifested five episodes. The dog is normal between the episodes; idiopathic epilepsy is suspected. You wonder what the best treatment in a dog with presumed idiopathic epilepsy would be.

\section{Summary of the evidence}

\begin{tabular}{|c|c|}
\hline \multicolumn{2}{|l|}{ Law (2015) } \\
\hline Population: & Dogs with idiopathic epilepsy (Tier II). \\
\hline Sample size: & 21 dogs, $n=21$ \\
\hline Intervention details: & $\begin{array}{l}\text { Dogs were fed either ketogenic medium-chain TAG diet } \\
\text { (MCTD) or placebo diet for } 3 \text { months followed by a } \\
\text { subsequent respective switch of diet for a further } 3 \text { months. } \\
\text { - Seizure frequency, clinical and laboratory data were } \\
\text { collected and evaluated for twenty-one dogs completing the } \\
\text { study. }\end{array}$ \\
\hline Study design: & Blinded randomized placebo-controlled cross-over trial. \\
\hline Outcome Studied: & $\begin{array}{l}\text { Objective: To compare the MCTD with a standardized placebo diet in } \\
\text { chronically antiepileptic drug-treated dogs with idiopathic epilepsy. }\end{array}$ \\
\hline $\begin{array}{l}\text { Main Findings } \\
\text { (relevant to PICO question): }\end{array}$ & $\begin{array}{l}\text { - The data showed antiepileptic properties associated with } \\
\text { ketogenic diets and provided evidence for the efficacy of the } \\
\text { MCTD used in this study as a therapeutic option for epilepsy } \\
\text { treatment. } \\
\text { Seizure frequency was significantly lower when dogs were } \\
\text { fed the MCTD }(2 \cdot 31 / \text { month, } 0-9 \cdot 89 / \text { month) in comparison } \\
\text { with the placebo diet }(2 \cdot 67 / \text { month, } 0 \cdot 33-22 \cdot 92 / \text { month, } \\
P=0 \cdot 020) ; \text { three dogs achieved seizure freedom, seven } \\
\text { additional dogs had } \geq 50 \% \text { reduction in seizure frequency, }\end{array}$ \\
\hline
\end{tabular}




\begin{tabular}{|c|c|}
\hline & $\begin{array}{l}\text { five had an overall }<50 \% \text { reduction in seizures }(38.87 \% \text {, } \\
35 \cdot 68-43 \cdot 27 \%) \text { and six showed no response. } \\
\text { There were no significant changes in serum concentrations } \\
\text { of glucose }(P=0.903) \text {, phenobarbital }(P=0.422) \text {, potassium } \\
\text { bromide }(P=0.404) \text { and weight }(P=0.300) \text { between diet } \\
\text { groups. }\end{array}$ \\
\hline Limitations: & $\begin{array}{l}\text { - Small number of dogs; however, calculations showed that it } \\
\text { should be adequate for this study. } \\
\text { - Risk of incomplete outcome data due to ten dogs } \\
\text { withdrawals; however reasons are thoroughly explained by } \\
\text { the authors and in this case they might not have changed } \\
\text { the final outcome. } \\
\text { - Also, these ten dogs were not included in the total number } \\
\text { of } 21 \text { dogs initially recruited and finally completed the data. } \\
\text { - The study had financial support by a food company, } \\
\text { although it is stated that the company was not involved with } \\
\text { the study design and data analysis. }\end{array}$ \\
\hline
\end{tabular}

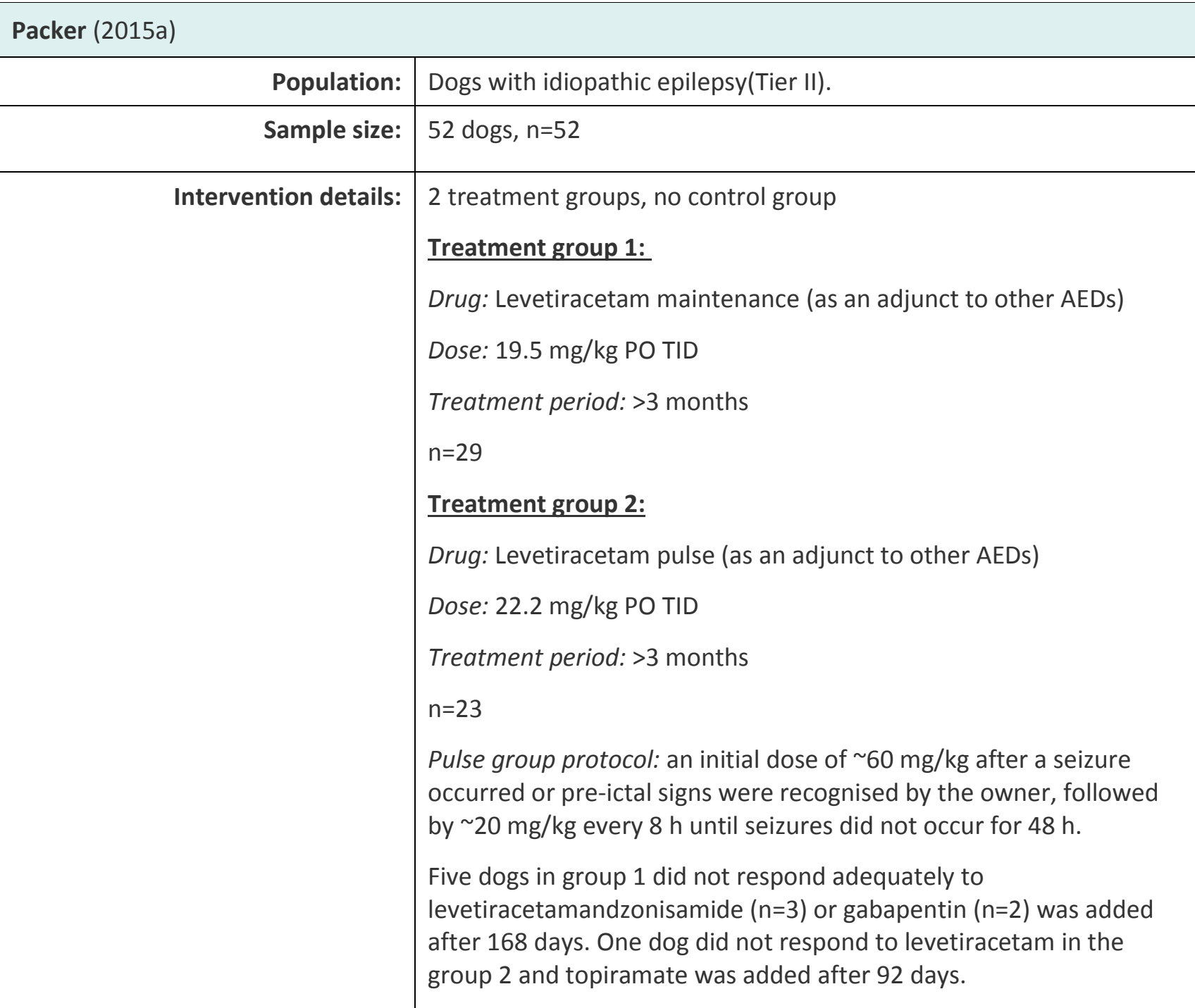




\begin{tabular}{|r|l|}
\hline Study design: & Retrospective case series. \\
\hline Outcome Studied: & $\begin{array}{l}\text { Objective: Evaluation of the antiepileptic action of levetiracetam } \\
\text { based mainly on the seizure frequency change during specific } \\
\text { treatment period. }\end{array}$ \\
\hline Main Findings & $\begin{array}{l}\text { Favourable results for levetiracetam. The treatment resulted } \\
\text { in } 69 \% \text { of dogs having }>50 \% \text { reduction in seizure frequency } \\
\text { whilst } 15 \% \text { of all the dogs were completely free from } \\
\text { seizures. }\end{array}$ \\
& $\begin{array}{l}\text { Seizure frequency reduced significantly in the whole } \\
\text { population. }\end{array}$ \\
& $\begin{array}{l}\text { Levetiracetam pulse might be a treatment for cluster } \\
\text { seizures. }\end{array}$ \\
\hline Limitations: & $\begin{array}{l}\text { Retrospective case series but mainly good follow up time } 1.1 \text { years } \\
\text { (median). }\end{array}$ \\
\hline
\end{tabular}

\begin{tabular}{|r|l|}
\hline \multicolumn{2}{|l|}{ Rundfeldt (2015) } \\
\hline Population: & Dogs with idiopathic epilepsy. (Tier I-II). \\
\hline Sample size: & 120 dogs, $\mathrm{n}=120$ \\
\hline Intervention details: & $\begin{array}{l}2 \text { treatment groups (including the control group) } \\
\text { Blinded part: } \\
\text { Treatment group 1: } \\
\text { Drug: Imepitoin } \\
\text { Dose:30 mg/kg PO BID } \\
\text { Treatment period:3 months } \\
\mathrm{n}=66 \\
\text { Treatment (control) group 2: } \\
\text { Drug:Imepitoin } \\
\text { Dose:1 mg/kg PO BID } \\
\text { Treatment period:3 months } \\
\mathrm{n}=61 \\
\text { Open-labelled follow-up: } \\
\text { Only 1 treatment group: } \\
\text { Drug: Imepitoin } \\
\text { Dose:30 mg/kg PO BID } \\
\text { Treatment period: 3 months } \\
\mathrm{n}=100\end{array}$ \\
\hline
\end{tabular}




\begin{tabular}{|c|c|}
\hline Study design: & $\begin{array}{l}\text { Blinded, randomised, controlled clinical trial (first phase) with an } \\
\text { open-labelled follow-up (second phase). }\end{array}$ \\
\hline Outcome Studied: & $\begin{array}{l}\text { Objective: } \\
\text { To support the antiepileptic activity and safety of imepitoin in dogs } \\
\text { with idiopathic epilepsy. }\end{array}$ \\
\hline $\begin{array}{l}\text { Main Findings } \\
\text { (relevant to PICO question): }\end{array}$ & $\begin{array}{l}\text { - Administration of imepitoin twice daily at a dose of } \\
30 \mathrm{mg} / \mathrm{kg} \text { results in significant and persistent antiepileptic } \\
\text { effects in patients with newly diagnosed epilepsy suffering } \\
\text { from generalized tonic-clonic seizures compared to } \\
\text { 'pseudoplacebo' control group ( } 1 \mathrm{mg} / \mathrm{kg} \text { BID) of the same } \\
\text { drug. } \\
\text { - The safety profile of imepitoin was good, and mostly CNS } \\
\text { related ARs were transient and predominantly observed in } \\
\text { the first weeks of treatment. }\end{array}$ \\
\hline Limitations: & $\begin{array}{l}\text { - Short follow up time for first phase of study ( } 12 \text { weeks). } \\
\text { - Open-labelled phase was an additional } 12 \text { weeks. } \\
\text { - A few cases had Tier I confidence level for the diagnosis of } \\
\text { idiopathic epilepsy. }\end{array}$ \\
\hline
\end{tabular}

\begin{tabular}{|c|c|}
\hline \multicolumn{2}{|l|}{ Tipold (2015) } \\
\hline Population: & Dogs with idiopathic epilepsy (Tier I). \\
\hline Sample size: & $\begin{array}{l}\text { - After exclusion: } 152, \mathrm{n}=152 \\
\text { - Before exclusion: } 195, \mathrm{n}=195\end{array}$ \\
\hline Intervention details: & $\begin{array}{l}1 \text { Treatment group, } 1 \text { Control group. } \\
\text { Treatment group: } \\
\text { Drug: Imepitoin } \\
\text { Dose: } 10-30 \mathrm{mg} / \mathrm{kgPO} \text { BID } \\
\text { Treatment period: } 5 \text { months } \\
\mathrm{n}=64 \text { (after exclusion), } \mathrm{n}=93 \text { (before exclusion) } \\
\text { Control group: } \\
\text { Drug: } \text { Phenobarbital } \\
\text { Dose: } 2-6 \text { mg/kgPO BID } \\
\text { Treatment period: } 5 \text { months } \\
\mathrm{n}=88 \text { (after exclusion), } \mathrm{n}=102 \text { (before exclusion) }\end{array}$ \\
\hline Study design: & Blinded, randomised, controlled clinical trial. \\
\hline
\end{tabular}




\begin{tabular}{|r|r|r|}
\hline Outcome Studied: & $\begin{array}{l}\text { Objective: Evaluation of the antiepileptic action of imepitoin and } \\
\text { phenobarbital based mainly on the seizure frequency change during } \\
\text { specific treatment period. }\end{array}$ \\
\hline (relevant to PICO question): & $\begin{array}{l}\text { The majority of the dogs were managed successfully with } \\
\text { imepitoin. }\end{array}$ \\
\hline Limitations: & $\begin{array}{l}\text { The same study confirmed non-inferiority of imepitoin to } \\
\text { phenobarbital. }\end{array}$ \\
\hline $\begin{array}{l}\text { Statistical analysis was conducted before unblinding only on } \\
\text { the per-protocol population and not on the intent-to-treat } \\
\text { population. }\end{array}$ \\
$\begin{array}{r}\text { Tier I confidence level for the diagnosis of idiopathic } \\
\text { epilepsy. }\end{array}$
\end{tabular}

\begin{tabular}{|c|c|}
\hline \multicolumn{2}{|l|}{ Charalambous (2014) } \\
\hline Population: & Dogs with idiopathic epilepsy. \\
\hline Sample size: & 1153 dogs, $n=1153$ \\
\hline Intervention details: & $\begin{array}{l}\text { Studies were grouped based on the antiepileptic drugs they } \\
\text { evaluated and their overall quality of evidence. Details of drug's } \\
\text { doses, treatment period, pre- and post- treatment seizure } \\
\text { frequency, } 95 \% \text { confidence interval of the successfully ( } \geq 50 \% \\
\text { reduction in seizure frequency) study population were provided. }\end{array}$ \\
\hline Study design: & Systematic Review. \\
\hline Outcome Studied: & $\begin{array}{l}\text { Objective: Individual studies were evaluated based on the quality of } \\
\text { evidence (study design, study group sizes, diagnostic procedures for } \\
\text { enrolling dogs with idiopathic epilepsy and overall risk of bias) and } \\
\text { the outcome measures reported (in particular the proportion of } \\
\text { dogs with } \geq 50 \% \text { reduction in seizure frequency). }\end{array}$ \\
\hline \multirow[t]{4}{*}{$\begin{array}{r}\text { Main Findings } \\
\text { (relevant to PICO question): }\end{array}$} & $\begin{array}{l}\text { - Overall risk of bias was moderate/high to high in } 85 \% \text { of the } \\
\text { studies included. }\end{array}$ \\
\hline & $\begin{array}{l}\text { - The diagnostic investigation procedures were poorly defined } \\
\text { or unclear in } 50 \% \text { of the studies. }\end{array}$ \\
\hline & $\begin{array}{l}\text { - Small population of dogs }(<20) \text { included in } 77 \% \text { of the } \\
\text { studies. }\end{array}$ \\
\hline & $\begin{array}{l}\text { Oral phenobarbital and imepitoin in particular, as well as } \\
\text { potassium bromide and levetiracetam are likely to be } \\
\text { effective for the treatment of IE. }\end{array}$ \\
\hline Limitations: & $\begin{array}{l}\text { - The review was an in depth and objective assessment of the } \\
\text { drugs' efficacy and studies' quality of evidence. Therefore, } \\
\text { the limitations occurred in this review, derived from the } \\
\text { studies included and evaluated in this review. }\end{array}$ \\
\hline
\end{tabular}




\begin{tabular}{|l|l|}
\hline - & $\begin{array}{l}\text { Precisely: the overall low quality of evidence; the variations } \\
\text { in baseline characteristics of the dogs involved; the } \\
\text { significant differences between study designs, and several } \\
\text { potential sources of bias that were identified preclude } \\
\text { definitive recommendations. } \\
\text { - The main limitation of this review is that it did not have free } \\
\text { full access to unpublished data (e.g. EMEA report). }\end{array}$ \\
\hline
\end{tabular}

\begin{tabular}{|c|c|}
\hline \multicolumn{2}{|l|}{ Freds $\varnothing(2014)$} \\
\hline Population: & $\begin{array}{l}\text { Dogs with idiopathic epilepsy (Tier I or insufficient level of } \\
\text { confidence) and structural epilepsy. }\end{array}$ \\
\hline Sample size: & 102 dogs, $n=102$ \\
\hline Intervention details: & $\begin{array}{l}\text { One hundred and two client owned dogs; } 78 \text { dogs with } \\
\text { idiopathic epilepsy and } 24 \text { dogs with epilepsy associated } \\
\text { with a known intracranial cause. } \\
\text { - A retrospective hospital based study with follow-up. Dogs } \\
\text { diagnosed with epilepsy between } 2002 \text { and } 2008 \text { were } \\
\text { enrolled in the study. } \\
\text { - Owners were interviewed by telephone using a structured } \\
\text { questionnaire addressing epilepsy status, treatment, } \\
\text { death/alive, and cause of death. }\end{array}$ \\
\hline Study design: & Retrospective case series. Questionnaire. \\
\hline Outcome Studied: & $\begin{array}{l}\text { Objective: To investigate risk factors for survival and duration of } \\
\text { survival in a population of dogs with idiopathic epilepsy or epilepsy } \\
\text { associated with a known intracranial cause. }\end{array}$ \\
\hline $\begin{array}{l}\text { Main Findings } \\
\text { (relevant to PICO question): }\end{array}$ & $\begin{array}{l}\text { In dogs where monotherapy was not sufficient, the need for } \\
\text { treatment with two AED's is not linked to a poor prognosis. }\end{array}$ \\
\hline Limitations: & $\begin{array}{l}\text { - Retrospective case series - questionnaire. } \\
\text { - Insufficient or Tier I confidence level for diagnosing } \\
\text { idiopathic epilepsy. }\end{array}$ \\
\hline
\end{tabular}

\begin{tabular}{|r|l|}
\hline Packer (2014) & \multicolumn{2}{|l|}{} \\
\hline Population: & Dogs with idiopathic epilepsy (Tier II). \\
\hline Intervention details: & 344 dogs, $\mathrm{n}=344$ \\
\hline & $\begin{array}{l}\text { Data from dogs was retrospectively collected from electronic patient } \\
\text { records. Clinical data was originally gained via standardised owner } \\
\text { questionnaires for epilepsy patients at their first appointment, and } \\
\text { longitudinal follow up data was gained via telephone interview with } \\
\text { the dogs' owners. }\end{array}$ \\
\hline
\end{tabular}




\begin{tabular}{|r|l|}
\hline Study design: & Retrospective case series. \\
\hline Outcome Studied: & $\begin{array}{l}\text { Objective: To identify clinical risk factors associated with } \\
\text { antiepileptic drug responsiveness in canine epilepsy. }\end{array}$ \\
\hline $\begin{array}{r}\text { Main Findings } \\
\text { (relevant to PICO question): }\end{array}$ & $\begin{array}{l}\text { The presence of cluster seizures and thus seizure density is a more } \\
\text { influential risk factor on the likelihood of achieving remission in } \\
\text { canine epilepsy than seizure frequency or the total number of } \\
\text { seizures prior to treatment. }\end{array}$ \\
\hline Limitations: & $\begin{array}{l}\text { Retrospective case series study. } \\
\text { However, thorough statistics were used which were good in } \\
\text { filtering out the non-significant. }\end{array}$ \\
\hline
\end{tabular}

\begin{tabular}{|c|c|}
\hline \multicolumn{2}{|l|}{ Kiviranta (2013) } \\
\hline Population: & Dogs with idiopathic epilepsy (Tier I). \\
\hline Sample size: & 10 dogs, $n=10$ \\
\hline Intervention details: & $\begin{array}{l}1 \text { Treatment group, no Control group. } \\
\text { Treatment group: } \\
\text { Drug: Topiramate as an adjunct to phenobarbital and/or potassium } \\
\text { bromide and/or levetiracetam } \\
\text { Dose: } 5 \mathrm{mg} / \mathrm{kg} \text { PO BID for } 2 \text { months, then } 10 \mathrm{mg} / \mathrm{kg} \text { PO BID for } 2 \\
\text { months and then } 10 \mathrm{mg} / \mathrm{kg} \text { PO TID for } 2 \text { months; doses of other } \\
\text { AEDs were not available but reported to be within normal reference } \\
\text { values } \\
\text { Treatment period: } 6-15 \text { months } \\
\mathrm{n}=10\end{array}$ \\
\hline Study design: & Uncontrolled clinical trial. \\
\hline Outcome Studied: & $\begin{array}{l}\text { Objective: Evaluation of the antiepileptic action of topiramate based } \\
\text { mainly on the seizure frequency change during specific treatment } \\
\text { period. }\end{array}$ \\
\hline $\begin{array}{l}\text { Main Findings } \\
\text { (relevant to PICO question): }\end{array}$ & $\begin{array}{l}\text { - Favourable results for topiramate adjunctive therapy. } \\
\text { - Approximately half of the study population had } \geq 50 \% \\
\text { reduction in seizure frequency. }\end{array}$ \\
\hline Limitations: & $\begin{array}{l}\text { - Non-blinded, non-randomised and uncontrolled trial. } \\
\text { - Low study population. } \\
\text { - Precise doses of concurrent AEDs were not reported. } \\
\text { - Tier I confidence level for the diagnosis of idiopathic } \\
\text { - epilepsy. }\end{array}$ \\
\hline
\end{tabular}




\begin{tabular}{|c|c|}
\hline \multicolumn{2}{|l|}{ Srivastava (2013) } \\
\hline Population: & Dogs with idiopathic epilepsy (insufficient level of confidence). \\
\hline Sample size: & 6 dogs, $n=6$ \\
\hline Intervention details: & $\begin{array}{l}1 \text { Treatment group, no Control group. } \\
\text { Treatment group: } \\
\text { Drug: potassium bromide as an adjunct to phenobarbital } \\
\text { Dose: potassium bromide: } 30 \mathrm{mg} / \mathrm{kg} \text { PO SID; phenobarbital: } 4.25 \\
\mathrm{mg} / \mathrm{kg} \text { PO BID } \\
\text { Treatment period: } 6 \text { months } \\
\mathrm{n}=6\end{array}$ \\
\hline Study design: & Uncontrolled clinical trial. \\
\hline Outcome Studied: & $\begin{array}{l}\text { Objective: Evaluation of the antiepileptic action of potassium } \\
\text { bromide based mainly on the seizure frequency change during } \\
\text { specific treatment period. }\end{array}$ \\
\hline $\begin{array}{r}\text { Main Findings } \\
\text { (relevant to PICO question): }\end{array}$ & $\begin{array}{l}\text { Favourable results for potassium bromide adjunctive therapy in all } \\
\text { dogs. }\end{array}$ \\
\hline Limitations: & $\begin{array}{l}\text { - Only abstract was retrieved. Low study population. } \\
\text { - Insufficient confidence level for the diagnosis of idiopathic } \\
\text { epilepsy. Precise reduction in seizure frequency could not be } \\
\text { detected only based on the abstract. } \\
\text { - Non-blinded, non-randomized, uncontrolled trial. }\end{array}$ \\
\hline
\end{tabular}

\begin{tabular}{|c|c|}
\hline Boothe (2012) & \\
\hline Population: & Dogs with idiopathic epilepsy (Tier I). \\
\hline Sample size: & 43 dogs, $n=43$ \\
\hline Intervention details: & $\begin{array}{l}2 \text { Comparison treatment groups: } \\
\text { Treatment group 1: } \\
\text { Drug: Phenobarbital } \\
\text { Dose: mean 4.11, range } 3.9-4.9 \mathrm{mg} / \mathrm{kg} \text { PO BID } \\
\text { Treatment period: approximately } 6 \text { months } \\
\mathrm{n}=20 \\
\text { Treatment group 2: } \\
\text { Drug: Potassium bromide } \\
\text { Dose: mean } 30.6 \text {, range } 26-35 \mathrm{mg} / \mathrm{kg} \text { PO BID } \\
\text { Treatment period: approximately } 6 \text { months } \\
\mathrm{n}=23\end{array}$ \\
\hline
\end{tabular}




\begin{tabular}{|r|r|}
\hline Study design: & Blinded, randomised, controlled clinical trial. \\
\hline Outcome Studied: & $\begin{array}{l}\text { Objective: Evaluation of the antiepileptic action of phenobarbital in } \\
\text { comparison to potassium bromide based mainly on the seizure } \\
\text { frequency change during specific treatment period. }\end{array}$ \\
\hline (relevant to PICO question): & $\begin{aligned} \text { Main Findings } \\
\text { monotherapy. }\end{aligned}$ \\
& $\begin{array}{l}\text { The majority of the study population had } \geq 50 \% \text { reduction in } \\
\text { seizure frequency in both groups. The percentage of } \\
\text { successfully treated cases was higher in phenobarbital } \\
\text { group. }\end{array}$ \\
\hline Limitations: & $\begin{array}{l}\text { Phenobarbital treated dogs had less side effects than } \\
\text { potassium bromide dogs. }\end{array}$ \\
\hline & Tier I confidence level for diagnosing idiopathic epilepsy. \\
\hline
\end{tabular}

\begin{tabular}{|c|c|}
\hline \multicolumn{2}{|l|}{ Chung (2012) } \\
\hline Population: & Dogs with idiopathic epilepsy (Tier II). \\
\hline Sample size: & 10 dogs, $n=10$ \\
\hline Intervention details: & $\begin{array}{l}1 \text { Treatment group, no Control group. } \\
\text { Treatment group: } \\
\text { Drug: Zonisamide } \\
\text { Dose: median 9.5, mean } 8.65 \text {, range } 2.5-12 \mathrm{mg} / \mathrm{kg} \text { PO BID } \\
\text { Treatment period: } 5 \text { median } 12 \text {, mean } 11.2 \text { months } \\
\mathrm{n}=10\end{array}$ \\
\hline Study design: & Uncontrolled clinical trial. \\
\hline Outcome Studied: & $\begin{array}{l}\text { Objective: Evaluation of the antiepileptic action of zonisamide } \\
\text { based mainly on the seizure frequency change during specific } \\
\text { treatment period. }\end{array}$ \\
\hline $\begin{array}{r}\text { Main Findings } \\
\text { (relevant to PICO question): }\end{array}$ & $\begin{array}{l}\text { Favourable results for zonisamide monotherapy. Approximately half } \\
\text { of the study population had } \geq 50 \% \text { reduction in seizure frequency. }\end{array}$ \\
\hline Limitations: & $\begin{array}{l}\text { - Non-blinded, non-randomised and uncontrolled trial. } \\
\text { - Low study population. } \\
\text { - } \quad \text { Research support but unclear if it was financial. }\end{array}$ \\
\hline
\end{tabular}

\begin{tabular}{|r|l|}
\hline \multicolumn{2}{|l|}{ Kis (2012) } \\
\hline Population: & Dogs with idiopathic epilepsy (Tier I). \\
\hline Sample size: & 70 dogs, $\mathrm{n}=70$ \\
\hline
\end{tabular}




\begin{tabular}{|c|c|}
\hline Intervention details: & $\begin{array}{l}1 \text { investigation group, no Control group. } \\
\text { Treatment group: } \\
\text { Drug: Phenobarbital } \\
\text { Dose: mean } 2.15 \text {, range } 0.65-10.44 \mathrm{mg} / \mathrm{kg} \text { PO BID } \\
\text { Treatment period: NA }\end{array}$ \\
\hline Study design: & Retrospective case series study. \\
\hline Outcome Studied: & $\begin{array}{l}\text { Objective: To determine the concentration of phenobarbital in dogs } \\
\text { with idiopathic epilepsy in Croatia. }\end{array}$ \\
\hline $\begin{array}{l}\text { Main Findings } \\
\text { (relevant to PICO question): }\end{array}$ & $\begin{array}{l}\text { - In the investigated population } 25 \text { patients (36\%) had } \\
\text { measured concentration of phenobarbital under the lower } \\
\text { therapeutic limit with adequate control of seizures. } \\
\text { - Only in } 16 \% \text { phenobarbital was ineffective in eradication of } \\
\text { seizures. } \\
\text { Phenobarbital is reasonable first-choice antiepileptic drug } \\
\text { for treatment of canine idiopathic epilepsy in Croatia. }\end{array}$ \\
\hline Limitations: & $\begin{array}{l}\text { - } \quad \text { Conference abstract. } \\
\text { - } \quad \text { Retrospective case series (high risk of bias). } \\
\text { - Tier I confidence level for diagnosing idiopathic epilepsy. }\end{array}$ \\
\hline
\end{tabular}

\begin{tabular}{|c|c|}
\hline \multicolumn{2}{|l|}{ Matthews (2012) } \\
\hline Population: & Dogs with idiopathic epilepsy (insufficient level of confidence). \\
\hline Sample size: & 15 dogs, $n=15$ \\
\hline Intervention details: & $\begin{array}{l}1 \text { Treatment group, } 1 \text { Control group: } \\
\text { - Treatment group: Fatty acid } \\
\text { - Placebo group: Olive oil } \\
\text { Twelve weeks of treatment with fatty acid supplementation, } \\
\text { followed by a 12-week placebo period of olive oil supplementation. }\end{array}$ \\
\hline Study design: & Blinded, placebo-controlled, clinical trial. \\
\hline Outcome Studied: & $\begin{array}{l}\text { Objective: Evaluation of the effect of fatty acid supplementation } \\
\text { based mainly on the seizure frequency change during specific } \\
\text { treatment period. }\end{array}$ \\
\hline $\begin{array}{l}\text { Main Findings } \\
\text { (relevant to PICO question): }\end{array}$ & $\begin{array}{l}\text { Fatty acid supplementation did not reduce seizure frequency or } \\
\text { severity in dogs with idiopathic epilepsy. }\end{array}$ \\
\hline Limitations: & $\begin{array}{l}\text { - Low study population. } \\
\text { - Non-randomised. }\end{array}$ \\
\hline
\end{tabular}




\begin{tabular}{|l|l|}
\hline & $\begin{array}{l}\text { - Short study duration. } \\
\bullet\end{array}$ \\
$\begin{array}{l}\text { Insufficient confidence level for diagnosing idiopathic } \\
\text { epilepsy. }\end{array}$ \\
\hline
\end{tabular}

Muñana et al. (2012)

\begin{tabular}{|c|c|}
\hline Population: & Dogs with idiopathic epilepsy (Tier I level of confidence). \\
\hline Sample size: & 34 dogs, $n=34$ \\
\hline Intervention details: & $\begin{array}{l}1 \text { Treatment group, } 1 \text { Control group. } \\
\text { Treatment group: } \\
\text { Drug: Levetiracetam as an adjunct to phenobarbital and/or } \\
\text { potassium bromide and/or levetiracetam and/or gabapentin } \\
\text { Dose: levetircetam: median 20.6, range } 17-23.1 \mathrm{mg} / \mathrm{kg} \text { PO TID; } \\
\text { phenobarbital: median 8.7, range2.9-17.2 mg/kg PO BID; } \\
\text { Potassium bromide: median 39.1; range } 13.6-133.3 \mathrm{mg} / \mathrm{kg} \text { PO SID } \\
\text { Treatment period: } 9 \text { months (during the } 5 \text { th month no antiepileptic } \\
\text { was administered) } \\
\mathrm{n}=22 \\
\text { Control group: } \\
\text { Drug: Placebo medication } \\
\text { Dose: NA } \\
\text { Treatment period: } 9 \text { months (during the 5th month no antiepileptic } \\
\text { was administered) } \\
\mathrm{n}=12\end{array}$ \\
\hline Study design: & Blinded, randomised, placebo-controlled clinical trial. \\
\hline Outcome Studied: & $\begin{array}{l}\text { Objective: Evaluation of the antiepileptic action of levetiracetam } \\
\text { based mainly on the seizure frequency change during specific } \\
\text { treatment period and compared to the placebo group. }\end{array}$ \\
\hline $\begin{array}{l}\text { Main Findings } \\
\text { (relevant to PICO question): }\end{array}$ & $\begin{array}{l}\text { - Favourable results for levetiracetam adjunctive therapy. } \\
\text { - The majority of the study population had } \geq 50 \% \text { reduction in } \\
\text { seizure frequency. } \\
\text { - The latter was reduced significantly compared to baseline } \\
\text { but no difference was detected when compared to the } \\
\text { placebo group (dogs in both the placebo and levetiracetam } \\
\text { group were on maintenance therapy with phenobarbital } \\
\text { and/or potassium bromide and/or gabapentin). }\end{array}$ \\
\hline Limitations: & $\begin{array}{l}\text { - Potential risk of comparing to retrospective baseline. } \\
\text { - The study had financial support but unclear if it influenced }\end{array}$ \\
\hline
\end{tabular}




\begin{tabular}{|l|l|}
\hline & the results. \\
& - Tier I confidence level for diagnosing idiopathic epilepsy. \\
\hline
\end{tabular}

\begin{tabular}{|c|c|}
\hline \multicolumn{2}{|l|}{ Jambroszyk (2011) } \\
\hline Population: & Dogs with idiopathic epilepsy (Tier I-II). \\
\hline Sample size: & 6 dogs, $n=6$ \\
\hline Intervention details: & $\begin{array}{l}1 \text { Treatment group, no Control group. } \\
\text { Treatment group: } \\
\text { Drug: Verapamil as an adjunct to phenobarbital } \\
\text { Dose: Verapamil: } 1-1.5 \mathrm{mg} / \mathrm{kg} \text { PO BID; phenobarbital: } 4 \mathrm{mg} / \mathrm{kg} \text { PO } \\
\text { SID } \\
\text { Treatment period: } 4 \text { months } \\
\mathrm{n}=6\end{array}$ \\
\hline Study design: & Uncontrolled clinical trial. \\
\hline Outcome Studied: & $\begin{array}{l}\text { Objective: Evaluation of the antiepileptic action of verapamil based } \\
\text { mainly on the seizure frequency change during specific treatment } \\
\text { period. }\end{array}$ \\
\hline $\begin{array}{l}\text { Main Findings } \\
\text { (relevant to PICO question): }\end{array}$ & Failure of the maximum tolerated dose to improve seizure control. \\
\hline Limitations: & $\begin{array}{l}\text { - Non-blinded, non-randomised and uncontrolled trial. } \\
\text { - Low study population. } \\
\text { - Tier I confidence level for diagnosing idiopathic epilepsy for } \\
\text { some cases. }\end{array}$ \\
\hline
\end{tabular}

\begin{tabular}{|r|l|}
\hline \multicolumn{2}{|l|}{ Gaskill (2010) } \\
\hline Population: & Dogs with idiopathic epilepsy (insufficient level of confidence). \\
\hline Intervention details: & 62 dogs, $n=62$ \\
& $\begin{array}{l}2 \text { comparison treatment groups. Phenobarbital }(\mathrm{n}=30) \text { and } \\
\text { potassium bromide }(\mathrm{n}=32) \text { were compared as monotherapies for } 12 \\
\text { months. Details of doses are not given. }\end{array}$ \\
\hline Study design: & Open-labeled, randomised, controlled trial. \\
\hline Outcome Studied: & $\begin{array}{l}\text { Objective: To compare phenobarbital to potassium bromide } \\
\text { monotherapy. }\end{array}$ \\
\hline Main Findings & $\begin{array}{l}\text { Phenobarbital was more effective and better tolerated than } \\
\text { potassium bromide monotherapy. }\end{array}$ \\
\hline (relevant to PICO question):
\end{tabular}




\begin{tabular}{|c|c|}
\hline Limitations: & $\begin{array}{l}\text { - Conference paper. } \\
\text { - Non- blinded and non-randomised. Insufficient confidence } \\
\text { level for diagnosing idiopathic epilepsy. }\end{array}$ \\
\hline
\end{tabular}

\begin{tabular}{|c|c|}
\hline \multicolumn{2}{|l|}{ Dewey (2009) } \\
\hline Population: & Dogs with idiopathic epilepsy (Tier I-II). \\
\hline Sample size: & 9 dogs, $n=9$ \\
\hline Intervention details: & $\begin{array}{l}1 \text { Treatment group, no Control group. } \\
\text { Treatment group: } \\
\text { Drug: pregabalin as an adjunct to phenobarbital and potassium } \\
\text { bromide } \\
\text { Dose: pregabalin: } 2 \mathrm{mg} / \mathrm{kg} \text { PO TID (dose was increased up to until 3-4 } \\
\mathrm{mg} / \mathrm{kg} \text { PO TID); doses of other AEDs were not available but reported } \\
\text { to be within normal reference values } \\
\text { Treatment period: } 3 \text { months } \\
\mathrm{n}=9\end{array}$ \\
\hline Study design: & Uncontrolled clinical trial. \\
\hline Outcome Studied: & $\begin{array}{l}\text { Objective: Evaluation of the antiepileptic action of pregabalin based } \\
\text { mainly on the seizure frequency change during specific treatment } \\
\text { period. }\end{array}$ \\
\hline $\begin{array}{r}\text { Main Findings } \\
\text { (relevant to PICO question): }\end{array}$ & $\begin{array}{l}\text { - Favourable results for pregabalin adjunctive therapy. } \\
\text { - The majority of the study population had } \geq 50 \% \text { reduction in } \\
\text { seizure frequency. }\end{array}$ \\
\hline Limitations: & $\begin{array}{l}\text { - Non-blinded, non-randomised and uncontrolled trial } \\
\text { - } \quad \text { Low study population. } \\
\text { - Short follow up - } 3 \text { months study duration. } \\
\text { - Precise doses of concurrent AEDs were not reported. } \\
\text { - Tier I confidence level for diagnosing idiopathic epilepsy for } \\
\text { some cases. }\end{array}$ \\
\hline
\end{tabular}

\begin{tabular}{|r|l|}
\hline \multicolumn{2}{|l|}{ Scorza (2009) } \\
\hline Population: & Dog with idiopathic epilepsy (insufficient level of confidence). \\
\hline Sample size: & $1 \mathrm{dog}, \mathrm{n}=1$ \\
\hline Intervention details: & $\begin{array}{l}1 \text { case. } \\
\text { Supplement the dog's diet with moderate amounts of fish oil (oral } \\
\text { omega-3 polyunsaturated fatty acids, } 2 \text { g/day). Phenobarbital (2.5 } \\
\mathrm{mg} / \mathrm{kg}, \text { twice a day orally) }\end{array}$ \\
\hline
\end{tabular}




\begin{tabular}{|r|l|}
\hline Study design: & Case report. \\
\hline Outcome Studied: & $\begin{array}{l}\text { Subjective: To evaluate the effectiveness of daily intake of a } \\
\text { moderate amount of fish oil in a case of canine epilepsy. }\end{array}$ \\
\hline Main Findings & $\begin{array}{r}\text { The frequency of the epileptic seizures markedly fell after } 50 \\
\text { days of combination therapy with phenobarbital and omega- } \\
3 \text { fatty acid. }\end{array}$ \\
\hline Limitations: & $\begin{array}{l}\text { During the subsequent 18-month period, seizure frequency } \\
\text { fell to one per } 3 \text { months, a reduction of about } 85 \% .\end{array}$ \\
\hline $\begin{array}{l}\text { - } \begin{array}{l}\text { Case report (high risk of bias). } \\
\text { epilepsy. }\end{array} \\
\text { - Insufficient details on the type of fish oil used or specific } \\
\text { concentrations. }\end{array}$ \\
\hline
\end{tabular}

\begin{tabular}{|c|c|}
\hline Volk (2009) & \\
\hline Population: & Dogs with idiopathic epilepsy (Tier II level of confidence). \\
\hline Sample size: & 22 dogs, $n=22$ \\
\hline Intervention details: & $\begin{array}{l}1 \text { Treatment group, no Control group. } \\
\text { Treatment group: } \\
\text { Drug: Levetiracetam as an adjunct to phenobarbital and potassium } \\
\text { bromide } \\
\text { Dose: levetircetam: } 10 \mathrm{mg} / \mathrm{kg} \text { for } 2 \text { months, } 20 \mathrm{mg} / \mathrm{kg} \text { for further } 2 \\
\text { months, } 10-20 \mathrm{mg} / \mathrm{kg} \text { for further } 2 \text { months and then } 10-20 \mathrm{mg} / \mathrm{kg} \\
\text { long-term PO TID; doses of other AEDs were not available but } \\
\text { reported to be within normal reference values } \\
\text { Treatment period: } 2-6 \text { months or more } \\
\mathrm{n}=14 \\
\text { This study included also a retrospective case series part: } \\
\text { Drug: Levetiracetam as an adjunct to phenobarbital and potassium } \\
\text { bromide } \\
\text { Dose: levetircetam: median } 22.15 \text {, mean } 21.7 \text {, range } 10-32.8 \mathrm{mg} / \mathrm{kg} \\
\text { PO TID; doses of other AEDs were not available but reported to be } \\
\text { within normal reference values } \\
\text { Treatment period: approximately } 2-3 \text { months } \\
\mathrm{n}=8\end{array}$ \\
\hline Study design: & Uncontrolled clinical trial. \\
\hline Outcome Studied: & $\begin{array}{l}\text { Objective: Evaluation of the antiepileptic action of levetiracetam } \\
\text { based mainly on the seizure frequency change during specific }\end{array}$ \\
\hline
\end{tabular}




\begin{tabular}{|c|c|}
\hline & treatment period. \\
\hline $\begin{array}{l}\text { Main Findings } \\
\text { (relevant to PICO question): }\end{array}$ & $\begin{array}{l}\text { - Favourable results for levetiracetam adjunctive therapy. } \\
\text { - The majority of the study population had } \geq 50 \% \text { reduction in } \\
\text { seizure frequency in both, clinical trial and case series part. }\end{array}$ \\
\hline Limitations: & $\begin{array}{l}\text { - Non-blinded, non-randomised and uncontrolled trial. } \\
\text { - The study had financial support but unclear if it influenced } \\
\text { the results. } \\
\text { - Part of the study was retrospective. } \\
\text { - Precise doses of concurrent AEDs were not reported; but } \\
\text { phenobarbital and potassium bromide serum levels were } \\
\text { reported. }\end{array}$ \\
\hline
\end{tabular}

\begin{tabular}{|c|c|}
\hline Population: & Dogs with idiopathic epilepsy(insufficient level of confidence). \\
\hline Sample size: & 11 dogs, $n=11$ \\
\hline Intervention details: & $\begin{array}{l}1 \text { Treatment group, no Control group. } \\
\text { Treatment group: } \\
\text { Drug: gabapentin as an adjunct to phenobarbital } \\
\text { Dose: gabapentin: mean } 40 \mathrm{mg} / \mathrm{kg} \text { PO BID; initial doses of other } \\
\text { AEDs were not available based on the abstract only } \\
\text { Treatment period: Unclear } \\
\mathrm{n}=11\end{array}$ \\
\hline Study design: & Uncontrolled clinical trial. \\
\hline Outcome Studied: & $\begin{array}{l}\text { Objective: Evaluation of the antiepileptic action of gabapentin based } \\
\text { mainly on the seizure frequency change during specific treatment } \\
\text { period. }\end{array}$ \\
\hline $\begin{array}{l}\text { Main Findings } \\
\text { (relevant to PICO question): }\end{array}$ & $\begin{array}{l}\text { - Favourable results for gabapentin as adjunctive therapy. } \\
\text { Significant reduction in frequency of epileptic attacks } \\
(67.29+\text { +or-9.03\%) in the majority of the dogs (7 patients) } \\
(63.63 \%) \text { allowing a progressive reduction in the PB doses to } \\
5 \mathrm{mg} / \mathrm{kg} \text { PO BID. }\end{array}$ \\
\hline Limitations: & $\begin{array}{l}\text { - Non-blinded, non-randomised, uncontrolled trial. } \\
\text { - Only abstract was retrieved. Low study population. } \\
\text { - Insufficient confidence level for diagnosing idiopathic } \\
\text { epilepsy. }\end{array}$ \\
\hline
\end{tabular}




\begin{tabular}{|c|c|}
\hline \multicolumn{2}{|l|}{ Varshney (2007) } \\
\hline Population: & $\begin{array}{l}\text { Dogs with idiopathic epilepsy seizures (insufficient level of } \\
\text { confidence) and head tremors. }\end{array}$ \\
\hline Sample size: & 10 dogs, $n=10$ \\
\hline Intervention details: & $\begin{array}{l}1 \text { Treatment group, no Control group. } \\
\text { Treatment group: } \\
\text { Belladona was administerd for approximately } 8 \text { months in all the } \\
\text { dogs and cocculus for approximately } 3 \text { months in } 4 \text { dogs of the } \\
\text { group. No other drug was used. }\end{array}$ \\
\hline Study design: & Uncontrolled clinical trial. \\
\hline Outcome Studied: & $\begin{array}{l}\text { Objective: Evaluation of the antiepileptic action of belladonna and } \\
\text { cocculus based mainly on the seizure frequency change during } \\
\text { specific treatment period. }\end{array}$ \\
\hline $\begin{array}{l}\text { Main Findings } \\
\text { (relevant to PICO question): }\end{array}$ & $\begin{array}{l}\text { Seizure-free status was achieved during the treatment period, but } \\
20 \% \text { of the dogs had again seizures } 15-25 \text { days after Belladona } \\
\text { stopped. Then, it was restarted for } 2-3 \text { months until seizures were } \\
\text { ceased. }\end{array}$ \\
\hline Limitations: & $\begin{array}{l}\text { - Non-blinded, non-randomised and uncontrolled trial. } \\
\text { - Controversial results. } \\
\text { - Unclear/Insufficient confidence level for diagnosing } \\
\text { idiopathic epilepsy. }\end{array}$ \\
\hline
\end{tabular}

\begin{tabular}{|r|l|}
\hline \multicolumn{2}{|c|}{ Von Klopmann (2007) } \\
\hline \multicolumn{1}{|c|}{ Population: } & Dogs with idiopathic epilepsy (Tier I-II level of confidence). \\
\hline Sample size: & 11 dogs, $\mathrm{n}=11$ \\
\hline Intervention details: & $\begin{array}{l}1 \text { Treatment group, no Control group. } \\
\text { Treatment group: }\end{array}$ \\
\hline $\begin{array}{l}\text { Drug: zonisamide as an adjunct to phenobarbital and/or potassium } \\
\text { bromide } \\
\text { Dose: zonisamide: mean } 8.9 \mathrm{mg} / \mathrm{kg}, \text { range } 5-11 \mathrm{mg} / \mathrm{kg} \text { PO BID; doses } \\
\text { of other AEDs were not available but reported to be within normal } \\
\text { reference values. } \\
\text { Treatment period: range 4-17 months } \\
\mathrm{n}=11\end{array}$ \\
\hline Study design: & Uncontrolled clinical trial. \\
\hline Outcome Studied: & $\begin{array}{l}\text { Objective: Evaluation of the antiepileptic action of zonisamide based } \\
\text { mainly on the seizure frequency change during specific treatment }\end{array}$ \\
\hline
\end{tabular}




\begin{tabular}{|c|c|}
\hline & period. \\
\hline $\begin{array}{l}\text { Main Findings } \\
\text { (relevant to PICO question): }\end{array}$ & $\begin{array}{l}\text { - Favourable results for zonisamide adjunctive therapy. } \\
\text { - The majority of the study population had } \geq 50 \% \text { reduction in } \\
\text { seizure frequency. }\end{array}$ \\
\hline Limitations: & $\begin{array}{l}\text { - Non-blinded, non-randomised and uncontrolled trial. } \\
\text { - Low study population. } \\
\text { - Precise doses of concurrent AEDs were not reported. } \\
\text { - Tier I confidence level for diagnosing idiopathic epilepsy for } \\
\text { some cases. }\end{array}$ \\
\hline
\end{tabular}

\begin{tabular}{|c|c|}
\hline \multicolumn{2}{|l|}{ Platt (2006) } \\
\hline Population: & Dogs with idiopathic epilepsy (Tier I level of confidence). \\
\hline Sample size: & 11 dogs, $n=11$ \\
\hline Intervention details: & 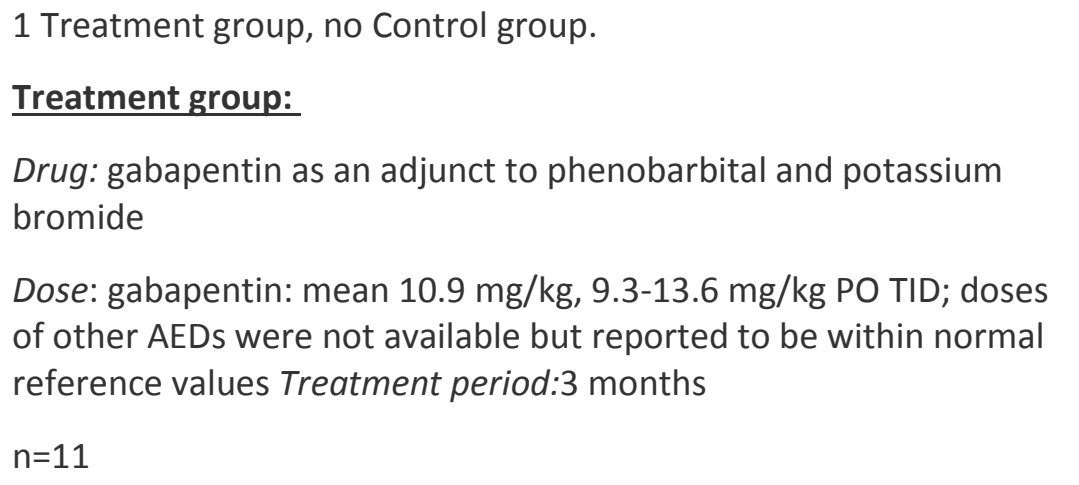 \\
\hline Study design: & Uncontrolled clinical trial. \\
\hline Outcome Studied: & $\begin{array}{l}\text { Objective: Evaluation of the antiepileptic action of gabapentin based } \\
\text { mainly on the seizure frequency change during specific treatment } \\
\text { period. }\end{array}$ \\
\hline $\begin{array}{l}\text { Main Findings } \\
\text { (relevant to PICO question): }\end{array}$ & $\begin{array}{l}\text { - Favourable results for gabapentin adjunctive therapy. } \\
\text { - Approximately half of the study population had } \geq 50 \% \\
\text { reduction in seizure frequency. }\end{array}$ \\
\hline Limitations: & $\begin{array}{l}\text { - Non-blinded, non-randomised and uncontrolled trial. } \\
\text { - Low study population. } \\
\text { - Less than } 6 \text { months study duration. Precise doses of } \\
\text { concurrent AEDs were not reported. } \\
\text { - Tier I confidence level for diagnosing idiopathic epilepsy. }\end{array}$ \\
\hline
\end{tabular}




\begin{tabular}{|c|c|}
\hline Population: & Dogs with idiopathic epilepsy (Tier I-II level of confidence). \\
\hline Sample size: & 143 dogs, $n=143$ \\
\hline Intervention details: &  \\
\hline Study design: & Uncontrolled clinical trial. \\
\hline Outcome Studied: & $\begin{array}{l}\text { Objective: Evaluation of the antiepileptic action of imepitoin, } \\
\text { phenobarbital and primidone monotherapy as well as potassium }\end{array}$ \\
\hline
\end{tabular}




\begin{tabular}{|r|r|}
\hline Main Findings & $\begin{array}{l}\text { bromide adjunctive treatment based mainly on the seizure } \\
\text { frequency change during specific treatment period. }\end{array}$ \\
\hline (relevant to PICO question): & $\begin{array}{l}\text { Only less than the half of the study population had } \geq 50 \% \\
\text { reduction in seizure frequency with imepitoin monotherapy, } \\
\text { imepitoin adjunctive therapy and potassium bromide } \\
\text { adjunctive therapy. }\end{array}$ \\
\hline Limitations: & $\begin{array}{l}\text { The majority of the study population had } \geq 50 \% \text { reduction in } \\
\text { seizure frequency with phenobarbital and primidone } \\
\text { monotherapy. }\end{array}$ \\
\hline $\begin{array}{l}\text { - Non-blinded, non-randomised and uncontrolled trial. } \\
\text { - Part of the study was retrospective. }\end{array}$ \\
$\begin{array}{l}\text { Tier I confidence level for diagnosing idiopathic epilepsy for } \\
\text { some cases. }\end{array}$ \\
\hline
\end{tabular}

\begin{tabular}{|c|c|}
\hline \multicolumn{2}{|l|}{ Govendir (2005) } \\
\hline Population: & Dogs with idiopathic epilepsy (Tier I level of confidence). \\
\hline Sample size: & 17 dogs, $n=17$ \\
\hline Intervention details: & $\begin{array}{l}1 \text { Treatment group, no Control group. } \\
\text { Treatment group: } \\
\text { Drug: gabapentin as an adjunct to phenobarbital and/or potassium } \\
\text { bromide } \\
\text { Dose: gabapentin: mean } 35 \mathrm{mg} / \mathrm{kg} \text {, range } 32-40 \mathrm{mg} / \mathrm{kg} \text { PO SID; } \\
\text { phenobarbital: median } 8 \mathrm{mg} / \mathrm{kg} \text {, range } 6-12 \mathrm{mg} / \mathrm{kg} \text { PO SID; } \\
\text { potassium bromide: median } 24 \mathrm{mg} / \mathrm{kg} \text {; range } 14-30 \mathrm{mg} / \mathrm{kg} \text { PO SID } \\
\text { Treatment period: } 4 \text { months } \\
\mathrm{n}=17\end{array}$ \\
\hline Study design: & Uncontrolled clinical trial. \\
\hline Outcome Studied: & $\begin{array}{l}\text { Objective: Evaluation of the antiepileptic action of gabapentin based } \\
\text { mainly on the seizure frequency change during specific treatment } \\
\text { period. }\end{array}$ \\
\hline $\begin{array}{r}\text { Main Findings } \\
\text { (relevant to PICO question): }\end{array}$ & $\begin{array}{l}\text { - Favourable results for gabapentin adjunctive therapy. } \\
\text { - Approximately more than the half of the study population } \\
\text { had } \geq 50 \% \text { reduction in seizure frequency. }\end{array}$ \\
\hline Limitations: & $\begin{array}{l}\text { - Non-blinded, non-randomised and uncontrolled trial. } \\
\text { - A few cases were treated by the referring vets. } \\
\text { - The study had financial support. } \\
\text { - Tier I confidence level for diagnosing idiopathic epilepsy for } \\
\text { some cases. }\end{array}$ \\
\hline
\end{tabular}




\begin{tabular}{|c|c|}
\hline \multicolumn{2}{|l|}{ Patterson (2005) } \\
\hline \multirow{2}{*}{$\begin{array}{r}\text { Population: } \\
\text { Sample size: }\end{array}$} & Dogs with idiopathic epilepsy (insufficient level of confidence). \\
\hline & 12 dogs, $n=12$ \\
\hline Intervention details: & $\begin{array}{l}1 \text { Treatment group, } 1 \text { Control group. } \\
\text { Treatment group: } \\
\text { Ketogenic food } \\
\text { Treatment period: } 6 \text { months } \\
\mathrm{n}=6 \\
\text { Control group: } \\
\text { Controlled food } \\
\text { Treatment period: } 6 \text { months } \\
\mathrm{n}=6\end{array}$ \\
\hline Study design: & Blinded, randomised, placebo- controlled clinical trial. \\
\hline Outcome Studied: & $\begin{array}{l}\text { Objective: Evaluation of the ketogenic food effectiveness in the } \\
\text { seizure control based mainly on the seizure frequency change during } \\
\text { specific treatment period. }\end{array}$ \\
\hline $\begin{array}{l}\text { Main Findings } \\
\text { (relevant to PICO question): }\end{array}$ & $\begin{array}{l}\text { - Only } 33 \% \text { of the study population had } \geq 50 \% \text { reduction in } \\
\text { seizure frequency. } \\
\text { - } \quad \text { No difference between two groups. }\end{array}$ \\
\hline Limitations: & $\begin{array}{l}\text { - Conference abstract. } \\
\text { - Doses/quantity of food or AEDs are not mentioned. } \\
\text { - Low study population. } \\
\text { - Needed } 22 \text { dogs per group based on power calculation; thus, } \\
\text { insufficient power in this study. } \\
\text { - Insufficient confidence level for diagnosing idiopathic } \\
\text { epilepsy. }\end{array}$ \\
\hline
\end{tabular}

\begin{tabular}{|r|l|}
\hline \multicolumn{2}{|l|}{ Dewey (2004) } \\
\hline Population: & Dogs with idiopathic epilepsy (Tier I-II level of confidence). \\
\hline Sample size: & 12 dogs, $\mathrm{n}=12$ \\
\hline Intervention details: & $\begin{array}{l}1 \text { Treatment group, no Control group. } \\
\text { Treatment group: }\end{array}$ \\
$\begin{array}{l}\text { Drug: zonisamide as an adjunct to phenobarbital and/or potassium } \\
\text { bromide }\end{array}$ \\
\hline
\end{tabular}




\begin{tabular}{|r|l|}
\hline & $\begin{array}{l}\text { Dose: zonisamide: mean } 8.9 \mathrm{mg} / \mathrm{kg} \text {, range 5-11mg/kg PO BID; doses } \\
\text { of other AEDs were not available but reduced or eliminated in 9/12 } \\
\text { dogs } \\
\text { Treatment period: mean 8, median 9, range 2 -18 months } \\
\mathrm{n}=17\end{array}$ \\
\hline Study design: & Uncontrolled clinical trial. \\
\hline Outcome Studied: & $\begin{array}{l}\text { Objective: Evaluation of the antiepileptic action of zonisamide based } \\
\text { mainly on the seizure frequency change during specific treatment } \\
\text { period. }\end{array}$ \\
\hline Main Findings & $\begin{array}{r}\text { - Favourable results for zonismide adjunctive therapy. } \\
\text { (relevant to PICO question): }\end{array}$ \\
\hline Limitations: & $\begin{array}{l}\text { Approximately half of the study population had } \geq 50 \% \\
\text { reduction in seizure frequency. }\end{array}$ \\
\hline $\begin{array}{l}\text { - Non-blinded, non-randomised and uncontrolled trial. } \\
\text { - Sow study population. }\end{array}$ & $\begin{array}{l}\text { Short follow-up period. } \\
\text { Tier I confidence level for diagnosing idiopathic epilepsy for } \\
\text { some cases. }\end{array}$ \\
\hline
\end{tabular}

\begin{tabular}{|c|c|}
\hline \multicolumn{2}{|l|}{ Steinberg (2004) } \\
\hline Population: & Dogs with idiopathic epilepsy (insufficient level of confidence). \\
\hline Sample size: & 15 dogs, $n=15$ \\
\hline Intervention details: & $\begin{array}{l}1 \text { Treatment group, no Control group. } \\
\text { Treatment group: } \\
\text { Drug: levetiracetam as an adjunct to phenobarbital and potassium } \\
\text { bromide } \\
\text { Dose: levetiracetam: range } 7.1-23.8 \mathrm{mg} / \mathrm{kg} \text { PO TID; doses of other } \\
\text { AEDs were not available but reported to be within normal reference } \\
\text { values } \\
\text { Treatment period: median } 38 \text {, range } 13.8-95.5 \text { months } \\
\mathrm{n}=15\end{array}$ \\
\hline Study design: & Uncontrolled clinical trial. \\
\hline Outcome Studied: & $\begin{array}{l}\text { Objective: Evaluation of the antiepileptic action of levetiracetam } \\
\text { based mainly on the seizure frequency change during specific } \\
\text { treatment period. }\end{array}$ \\
\hline $\begin{array}{l}\text { Main Findings } \\
\text { (relevant to PICO question): }\end{array}$ & $\begin{array}{l}\text { - Favourable results for levetiracetam adjunctive therapy. } \\
\text { - All the dogs of the study population had } \geq 50 \% \text { reduction in } \\
\text { seizure frequency. }\end{array}$ \\
\hline
\end{tabular}




\begin{tabular}{|l|l|}
\hline Limitations: & - Low study population. \\
& $\begin{array}{l}\text { - Insufficient confidence level for diagnosing idiopathic } \\
\end{array}$ \\
& epilepsy. \\
& - Non-blinded, non-randomised and uncontrolled trial. \\
& - Conference abstract. \\
\hline
\end{tabular}

\begin{tabular}{|c|c|}
\hline \multicolumn{2}{|l|}{ Muñana (2002) } \\
\hline Population: & Dogs with idiopathic epilepsy (Tier II confidence level). \\
\hline Sample size: & 10 dogs, $n=10$ \\
\hline Intervention details: & $\begin{array}{l}1 \text { Treatment group, } 1 \text { Control group. } \\
\text { Treatment group: } \\
\text { Vagal nerve stimulation adjunctive to phenobarbital and/or } \\
\text { potassium bromide and/or felbamate } \\
\text { Control Group: } \\
\text { No device } \\
\text { Method: } 13 \text { weeks of treatment followed (after } 4 \text { weeks wash-out) } \\
\text { by } 13 \text { weeks of control (inactive device) }\end{array}$ \\
\hline Study design: & Double blinded crossover controlled clinical trial \\
\hline Outcome Studied: & $\begin{array}{l}\text { Objective: To investigate the antiepileptic efficacy of vagal nerve } \\
\text { stimulation. }\end{array}$ \\
\hline $\begin{array}{l}\text { Main Findings } \\
\text { (relevant to PICO question): }\end{array}$ & $\begin{array}{l}\text { Mean decrease in seizure frequency between the } 2 \text { groups was } 5.1 \% \\
\text { and not significant. }\end{array}$ \\
\hline Limitations: & $\begin{array}{l}\text { - Low study population. } \\
\text { - Assessment bias in favor of the device introduced by } \\
\text { owners' assessment could be a possibility. }\end{array}$ \\
\hline
\end{tabular}

\begin{tabular}{|c|c|}
\hline \multicolumn{2}{|l|}{ Ruehlmann (2001) } \\
\hline Population: & Dogs with idiopathic epilepsy (Tier I-II level of confidence). \\
\hline Sample size: & 6 dogs, $n=6$ \\
\hline Intervention details: & $\begin{array}{l}1 \text { Treatment group, no Control group. } \\
\text { Treatment group: } \\
\text { Drug: felbamate as an adjunct to phenobarbital } \\
\text { Dose: felbamate: median } 63 \mathrm{mg} / \mathrm{kg} \text { (initial dose) and } 77 \mathrm{mg} / \mathrm{kg} \text { (final } \\
\text { dose) PO BID; phenobarbital: } 3.75 \mathrm{mg} / \mathrm{kg} \text { POBID (stopped } 2 \text { months } \\
\text { after felbamate started) }\end{array}$ \\
\hline
\end{tabular}




\begin{tabular}{|c|c|}
\hline & $\begin{array}{l}\text { Treatment period: median } 9 \text { months } \\
\mathrm{n}=6\end{array}$ \\
\hline Study design: & Uncontrolled clinical trial. \\
\hline Outcome Studied: & $\begin{array}{l}\text { Objective: Evaluation of the antiepileptic action of felbamate } \\
\text { adjunctive therapy based mainly on the seizure frequency change } \\
\text { during specific treatment period. }\end{array}$ \\
\hline $\begin{array}{l}\text { Main Findings } \\
\text { (relevant to PICO question): }\end{array}$ & $\begin{array}{l}\text { - Favourable results for felbamate adjunctive therapy. } \\
\text { - All the dogs of the study population had } \geq 50 \% \text { reduction in } \\
\text { seizure frequency. }\end{array}$ \\
\hline Limitations: & $\begin{array}{l}\text { - Non-blinded, non-randomised and uncontrolled trial. } \\
\text { - Low study population. } \\
\text { - Part of the study was retrospective. No clarification of } \\
\text { statistical analysis. } \\
\text { - Tier I confidence level for diagnosing idiopathic epilepsy for } \\
\text { some cases. }\end{array}$ \\
\hline
\end{tabular}

\begin{tabular}{|c|c|}
\hline Population: & Dogs with idiopathic epilepsy (insufficient level of confidence). \\
\hline Sample size: & 122 dogs, $n=122$ \\
\hline Intervention details: & $\begin{array}{l}1 \text { Treatment group, no Control group. } \\
\text { Treatment group: } \\
\text { Drug: potassium bromide as an adjunct to phenobarbital or } \\
\text { primidone } \\
\text { Dose: Doses were not available but adjusted according to the } \\
\text { therapeutic serum levels and clinical response } \\
\text { Treatment period: mean } 14.2+/-4.7 \text { months } \\
\mathrm{n}=6\end{array}$ \\
\hline Study design: & Retrospective case series study. \\
\hline Outcome Studied: & $\begin{array}{l}\text { Objective: Evaluation of the antiepileptic action of potassium } \\
\text { bromide as adjunctive therapy based mainly on the seizure } \\
\text { frequency change during specific treatment period. }\end{array}$ \\
\hline $\begin{array}{r}\text { Main Findings } \\
\text { (relevant to PICO question): }\end{array}$ & $\begin{array}{l}\text { Favourable results for potassium bromide adjunctive } \\
\text { therapy. } \\
\text { - The majority of the study population had } \geq 50 \% \text { reduction in } \\
\text { seizure frequency. }\end{array}$ \\
\hline Limitations: & $\begin{array}{l}\text { - Retrospective nature of study. } \\
\text { - Insufficient confidence level for diagnosing idiopathic } \\
\text { epilepsy. }\end{array}$ \\
\hline
\end{tabular}




\begin{tabular}{|c|c|}
\hline \multicolumn{2}{|l|}{ Heynold (1997) } \\
\hline Population: & Dogs with idiopathic epilepsy (tier I-II level of confidence). \\
\hline Sample size: & 37 dogs, $n=37$ \\
\hline Intervention details: & $\begin{array}{l}1 \text { Treatment group, no Control group. } \\
\text { Treatment group: } \\
\text { Drug: phenobarbital } \\
\text { Dose: mean } 2.5 \mathrm{mg} / \mathrm{kg} \text { PO BID } \\
\text { Treatment period: mean } 50.4 \text {, range } 8 \text {-18months } \\
\mathrm{n}=37\end{array}$ \\
\hline Study design: & Retrospective case series study. \\
\hline Outcome Studied: & $\begin{array}{l}\text { Objective: Evaluation of the antiepileptic action of phenobarbital } \\
\text { based mainly on the seizure frequency change during specific } \\
\text { treatment period. }\end{array}$ \\
\hline $\begin{array}{l}\text { Main Findings } \\
\text { (relevant to PICO question): }\end{array}$ & $\begin{array}{l}\text { - Favourable results for phenobarbital monotherapy. } \\
\text { - The majority of the study population had } \geq 50 \% \text { reduction in } \\
\text { seizure frequency. }\end{array}$ \\
\hline Limitations: & $\begin{array}{l}\text { - Retrospective nature of study. } \\
\text { - Less than } 6 \text { months study duration. } \\
\text { - The study had financial support but unclear if it influenced } \\
\text { the results. } \\
\text { - Tier I confidence level for diagnosing idiopathic epilepsy for } \\
\text { some cases. }\end{array}$ \\
\hline
\end{tabular}

\begin{tabular}{|r|l|}
\hline \multicolumn{2}{|l|}{ O'Brien (1997) } \\
\hline Population: & Dogs with idiopathic epilepsy (insufficient level of confidence). \\
\hline Sample size: & 10 dogs, $\mathrm{n}=10$ \\
\hline Intervention details: & $\begin{array}{l}1 \text { Treatment group, no Control group. } \\
\text { Treatment group: }\end{array}$ \\
& $\begin{array}{l}\text { Drug: nimodipine as an adjunct to phenobarbital or primidone. } \\
\text { Dose: nimodipine: } 2.5 \mathrm{mg} / \mathrm{kg} \text { PO BID; doses of phenobarbital or } \\
\text { primidone were ot available gradually tapered during a minimum of } \\
4 \text { weeks) } \\
\text { Treatment period: } 6 \text { months } \\
\mathrm{n}=10\end{array}$ \\
\hline
\end{tabular}




\begin{tabular}{|c|c|}
\hline Study design: & Uncontrolled clinical trial. \\
\hline Outcome Studied: & $\begin{array}{l}\text { Objective: Evaluation of the antiepileptic action of nimodipine as } \\
\text { adjunctive therapy based mainly on the seizure frequency change } \\
\text { during specific treatment period. }\end{array}$ \\
\hline $\begin{array}{r}\text { Main Findings } \\
\text { (relevant to PICO question): }\end{array}$ & Nimodipine was not successful in controlling seizures in dogs. \\
\hline Limitations: & $\begin{array}{l}\text { - Non-blinded, non-randomised and uncontrolled trial. } \\
\text { - Insufficient confidence level for diagnosing idiopathic } \\
\text { epilepsy. }\end{array}$ \\
\hline
\end{tabular}

\begin{tabular}{|c|c|}
\hline \multicolumn{2}{|l|}{ Podell (1993) } \\
\hline Population: & Dogs with idiopathic epilepsy (Tier I-II level of confidence) \\
\hline Sample size: & 37 dogs, $n=37$ \\
\hline Intervention details: & $\begin{array}{l}1 \text { Treatment group, no Control group. } \\
\text { Treatment group: } \\
\text { Drug: potassium bromide as an adjunct to phenobarbital } \\
\text { Dose: potassium bromide: mean } 20.75 \mathrm{mg} / \mathrm{kg} \text {, range } 13-40 \mathrm{mg} / \mathrm{kg} \\
\text { PO BID; phenobarbital: not available } \\
\text { Treatment period: mean } 15 \text {, range } 4-33 \text { months } \\
\mathrm{n}=37\end{array}$ \\
\hline Study design: & Retrospective case series study. \\
\hline Outcome Studied: & $\begin{array}{l}\text { Objective: Evaluation of the antiepileptic action of potassium } \\
\text { bromide as adjunctive therapy based mainly on the seizure } \\
\text { frequency change during specific treatment period. }\end{array}$ \\
\hline $\begin{array}{r}\text { Main Findings } \\
\text { (relevant to PICO question): }\end{array}$ & $\begin{array}{l}\text { - Favourable results for potassium bromide adjunctive } \\
\text { therapy. } \\
\text { - The majority of the study population had } \geq 50 \% \text { reduction in } \\
\text { seizure frequency. }\end{array}$ \\
\hline Limitations: & $\begin{array}{l}\text { - Retrospective case series. } \\
\text { - Tier I confidence level for diagnosing idiopathic epilepsy for } \\
\text { some cases. }\end{array}$ \\
\hline
\end{tabular}

Schwartz-Porsche (1991)

Population: $\quad$ Dogs with idiopathic epilepsy (Tier II level of confidence).

Sample size: 19 dogs, $n=19$ 


\begin{tabular}{|c|c|}
\hline Intervention details: & $\begin{array}{l}1 \text { Treatment group, no Control group. } \\
\text { Treatment group: } \\
\text { Drug: potassium bromide as an adjunct to phenobarbital or } \\
\text { primidone } \\
\text { Dose: potassium bromide: range } 17-58 \mathrm{mg} / \mathrm{kg} \text { PO SID; doses of other } \\
\text { AEDs were not available but reported to be within normal reference } \\
\text { values or kept in the maximum therapeutic doses } \\
\text { Treatment period: mean } 21 \text {, range, } 7-61 \text { months } \\
\mathrm{n}=19\end{array}$ \\
\hline Study design: & Uncontrolled clinical trial. \\
\hline Outcome Studied: & $\begin{array}{l}\text { Objective: Evaluation of the antiepileptic action of potassium } \\
\text { bromide as adjunctive therapy based mainly on the seizure } \\
\text { frequency change during specific treatment period. }\end{array}$ \\
\hline $\begin{array}{l}\text { Main Findings } \\
\text { (relevant to PICO question): }\end{array}$ & $\begin{array}{l}\text { - Favourable results for potassium bromide adjunctive } \\
\text { therapy. } \\
\text { More than half of the study population had } \geq 50 \% \text { reduction } \\
\text { in seizure frequency. }\end{array}$ \\
\hline Limitations: & Non-blinded, non-randomised and uncontrolled trial. \\
\hline
\end{tabular}

\begin{tabular}{|c|c|}
\hline \multicolumn{2}{|l|}{ Pearce (1990) } \\
\hline \multirow{2}{*}{$\begin{array}{r}\text { Population: } \\
\text { Sample size: }\end{array}$} & Dogs with idiopathic epilepsy (Tier I-II). \\
\hline & 10 dogs, $n=10$ \\
\hline Intervention details: & $\begin{array}{l}1 \text { Treatment group, no Control group. } \\
\text { Treatment group: } \\
\text { Drug: potassium bromide as an adjunct to phenobarbital } \\
\text { Dose: potassium bromide: } 22 \mathrm{PO} \text { SID (dose increases occurred); } \\
\text { phenobarbital: median } 3.3 \mathrm{mg} / \mathrm{kg} \text {, mean } 3.8 \mathrm{mg} / \mathrm{kg} \mathrm{PO} \mathrm{BID} \text { (dose was } \\
\text { reduced by a mean of } 50 \% \text { in } 7 / 10 \text { dogs during the } \mathrm{PBr} \text { treatment) } \\
\text { Treatment period: median } 7 \text {, mean } 7.8 \text { months } \\
\mathrm{n}=10\end{array}$ \\
\hline Study design: & Uncontrolled clinical trial. \\
\hline Outcome Studied: & $\begin{array}{l}\text { Objective: Evaluation of the antiepileptic action of potassium } \\
\text { bromide as adjunctive therapy based mainly on the seizure } \\
\text { frequency change during specific treatment period. }\end{array}$ \\
\hline $\begin{array}{l}\text { Main Findings } \\
\text { (relevant to PICO question): }\end{array}$ & $\begin{array}{l}\text { - Favourable results for potassium bromide adjunctive } \\
\text { therapy. } \\
\text { - The majority of the study population had } \geq 50 \% \text { reduction in } \\
\text { seizure frequency. }\end{array}$ \\
\hline
\end{tabular}




\begin{tabular}{|l|l|}
\hline Limitations: & $\begin{array}{l}\text { - Non-blinded, non-randomised and uncontrolled trial. } \\
\text { - Low study population. }\end{array}$ \\
& $\begin{array}{l}\text { - Tier I confidence level for diagnosing idiopathic epilepsy for } \\
\text { some cases. }\end{array}$ \\
\hline
\end{tabular}

\begin{tabular}{|c|c|}
\hline \multicolumn{2}{|l|}{ Morton (1988) } \\
\hline Population: & Dogs with idiopathic epilepsy (insufficient level of confidence). \\
\hline Sample size: & 19 dogs, $n=19$ \\
\hline Intervention details: & $\begin{array}{l}2 \text { treatment groups } \\
\text { Treatment group 1: } \\
\text { Drug: Phenobarbital } \\
\text { Dose: median } 180 \mathrm{mg} / \mathrm{kg} \text {, mean } 283 \mathrm{mg} / \mathrm{kg} \text {, range } 60-90 \mathrm{mg} / \mathrm{kg} \text { PO } \\
\text { SID } \\
\text { Treatment period: unclear } \\
\mathrm{n}=7 \\
\text { Treatment group 2: } \\
\text { Drug: primidone } \\
\text { Dose: median } 50 \mathrm{mg} / \mathrm{kg} \text {, mean } 48 \mathrm{mg} / \mathrm{kg} \text {, range } 18-94 \mathrm{mg} / \mathrm{kg} \text { PO SID } \\
\text { Treatment period: unclear } \\
\mathrm{n}=12\end{array}$ \\
\hline Study design: & Uncontrolled clinical trial. \\
\hline Outcome Studied: & $\begin{array}{l}\text { Objective: Evaluation of the antiepileptic action of primidone and } \\
\text { phenobarbital monotherapy based mainly on the seizure frequency } \\
\text { change during specific treatment period. }\end{array}$ \\
\hline $\begin{array}{l}\text { Main Findings } \\
\text { (relevant to PICO question): }\end{array}$ & $\begin{array}{l}\text { - Favourable results for primidone and phenobarbital } \\
\text { monotherapy } \\
\text { - The majority of the study population had } \geq 50 \% \text { reduction in } \\
\text { seizure frequency in primidone group. } \\
\text { - Approximately half of the study population had } \geq 50 \% \\
\text { reduction in seizure frequency in phenobarbital group. }\end{array}$ \\
\hline Limitations: & $\begin{array}{l}\text { - Non-blinded, non-randomised and uncontrolled trial. } \\
\text { - A few cases were treated by the referring vets. } \\
\text { - The study had financial support but unclear if it influenced } \\
\text { the results. Insufficient confidence level for diagnosing } \\
\text { idiopathic epilepsy. }\end{array}$ \\
\hline
\end{tabular}




\begin{tabular}{|c|c|}
\hline \multicolumn{2}{|l|}{ Schwartz-Porsche (1985) } \\
\hline Population: & Dogs with idiopathic epilepsy (insufficient level of confidence). \\
\hline Sample size: & 35 dogs, $n=35$ \\
\hline Intervention details: & $\begin{array}{l}2 \text { treatment groups } \\
\text { Treatment group 1: } \\
\text { Drug: Phenobarbital } \\
\text { Dose: mean } 15 \mathrm{mg} / \mathrm{kg} \text {, range } 7.3-32 \mathrm{mg} / \mathrm{kg} \text { PO SID } \\
\text { Treatment period: unclear } \\
\mathrm{n}=15 \\
\text { Treatment group 2: } \\
\text { Drug: primidone } \\
\text { Dose: range } 17-107 \mathrm{mg} / \mathrm{kg} \text { PO SID } \\
\text { Treatment period: mean 14, range 6.0-35months } \\
\mathrm{n}=20\end{array}$ \\
\hline Study design: & Open-labeled, randomized, controlled clinical trial. \\
\hline Outcome Studied: & $\begin{array}{l}\text { Objective: Evaluation of the antiepileptic action of primidone and } \\
\text { phenobarbital monotherapy based mainly on the seizure frequency } \\
\text { change during specific treatment period. }\end{array}$ \\
\hline $\begin{array}{l}\text { Main Findings } \\
\text { (relevant to PICO question): }\end{array}$ & $\begin{array}{l}\text { - Favourable results for phenobarbital and } \\
\text { primidonemonotherapy. } \\
\text { - The majority of the study population had } \geq 50 \% \text { reduction in } \\
\text { seizure frequency. }\end{array}$ \\
\hline Limitations: & $\begin{array}{l}\text { - Non-blinded. } \\
\text { - The study had research support but unclear if it influenced } \\
\text { the results. } \\
\text { - No clarification of statistical analysis. Insufficient confidence } \\
\text { level for diagnosing idiopathic epilepsy. }\end{array}$ \\
\hline
\end{tabular}

\begin{tabular}{|r|l|}
\hline \multicolumn{2}{|l|}{ Cunningham (1983) } \\
\hline Population: & Dogs with idiopathic epilepsy (Tier II level of confidence). \\
\hline Sample size: & 15 dogs, $\mathrm{n}=15$ \\
\hline Intervention details: & $\begin{array}{l}1 \text { Treatment group, no Control group. } \\
\text { Treatment group: }\end{array}$ \\
\hline
\end{tabular}




\begin{tabular}{|c|c|}
\hline & $\begin{array}{l}\text { Drug: primidone } \\
\text { Dose: unclear } \\
\text { Treatment period: } 9 \text { months } \\
\mathrm{n}=15\end{array}$ \\
\hline Study design: & Uncontrolled clinical trial. \\
\hline Outcome Studied: & $\begin{array}{l}\text { Objective: Evaluation of the antiepileptic action of primidonebased } \\
\text { mainly on the seizure frequency change during specific treatment } \\
\text { period. }\end{array}$ \\
\hline $\begin{array}{l}\text { Main Findings } \\
\text { (relevant to PICO question): }\end{array}$ & $\begin{array}{l}\text { - Favourable results for primidone monotherapy. } \\
\text { - The majority of the study population had } \geq 50 \% \text { reduction in } \\
\text { seizure frequency. }\end{array}$ \\
\hline Limitations: & $\begin{array}{l}\text { - Conference abstract. } \\
\text { - Non-blinded, non-randomised and uncontrolled trial. } \\
\text { - Low study population. }\end{array}$ \\
\hline
\end{tabular}

1. Schwartz-Porsche et al. (1982)

\begin{tabular}{|c|c|}
\hline Population: & Dogs with idiopathic epilepsy (Tier II level of confidence). \\
\hline Sample size: & 30 dogs, $n=30$ \\
\hline Intervention details: & $\begin{array}{l}1 \text { Treatment group, no Control group. } \\
\text { Treatment group: } \\
\text { Drug: primidone } \\
\text { Dose: } 13-100 \mathrm{mg} / \mathrm{kg} \text { PO SID } \\
\text { Treatment period: approximately } 6 \text { months } \\
\mathrm{n}=15\end{array}$ \\
\hline Study design: & Uncontrolled clinical trial. \\
\hline Outcome Studied: & $\begin{array}{l}\text { Objective: Evaluation of the antiepileptic action of primidone based } \\
\text { mainly on the seizure frequency change during specific treatment } \\
\text { period. }\end{array}$ \\
\hline $\begin{array}{l}\text { Main Findings } \\
\text { (relevant to PICO question): }\end{array}$ & $\begin{array}{l}\text { - Favourable results for primidone monotherapy. } \\
\text { - The majority of the study population had } \geq 50 \% \text { reduction in } \\
\text { seizure frequency. }\end{array}$ \\
\hline Limitations: & Non-blinded, non-randomised and uncontrolled trial. \\
\hline
\end{tabular}




\begin{tabular}{|c|c|}
\hline \multicolumn{2}{|l|}{ Nafe (1981) } \\
\hline Population: & Dogs with idiopathic epilepsy (Tier I-II level of confidence). \\
\hline Sample size: & 57 dogs, $n=57$ \\
\hline Intervention details: & $\begin{array}{l}4 \text { Treatment groups } \\
\text { Treatment group 1: } \\
\text { Drug: sodium valproate as an adjunct to phenobarbital and } \\
\text { phenytoin } \\
\text { Dose: sodium valproate: range } 25-40 \mathrm{mg} / \mathrm{kg} \text { PO SID; the doses of } \\
\text { other drugs were not reported } \\
\text { Treatment period: mean 4.9, range 1-8 months } \\
\mathrm{n}=11 \\
\text { Treatment group 2: } \\
\text { Drug: sodium valproate as an adjunct to primidone } \\
\text { Dose: sodium valproate: range } 30-45 \mathrm{mg} / \mathrm{kg} \text { PO SID; the doses of } \\
\text { other drugs were not reported } \\
\text { Treatment period: mean } 4.9, \text { range } 1-8 \text { months } \\
\mathrm{n}=6 \\
\text { Treatment group 3: } \\
\text { Drug: sodium valproate as an adjunct to phenobarbital } \\
\text { Dose: sodium valproate: range } 30-110 \mathrm{mg} / \mathrm{kg} \text { PO SID; the doses of } \\
\text { other drugs were not reported } \\
\text { Treatment period: mean } 4.9, \text { range } 1-8 \text { months } \\
\mathrm{n}=21 \\
\text { Treatment group 4: } \\
\text { Drug: sodium valproate } \\
\text { Dose: range } 25-105 \text { mg/kg PO SID; the doses of other drugs were not } \\
\text { reported } \\
\text { Treatment period: mean } 4.9, \text { range } 1-8 \text { months } \\
\mathrm{n}=16\end{array}$ \\
\hline Study design: & Uncontrolled clinical trial. \\
\hline Outcome Studied: & $\begin{array}{l}\text { Objective: Evaluation of the antiepileptic action of sodium valproate } \\
\text { as adjunctive therapy or monotherapy based mainly on the seizure } \\
\text { frequency change during specific treatment period. }\end{array}$ \\
\hline $\begin{array}{r}\text { Main Findings } \\
\text { (relevant to PICO question): }\end{array}$ & $\begin{array}{l}\text { - The majority of the study population did not have } \geq 50 \% \\
\text { reduction in seizure frequency in groups } 1,2 \text { and } 4 \text {. }\end{array}$ \\
\hline
\end{tabular}




\begin{tabular}{|l|l|}
\hline & $\begin{array}{l}\text { - In group 3, approximately half of the study population had } \\
\geq 50 \% \text { reduction in seizure frequency. }\end{array}$ \\
\hline Limitations: & $\begin{array}{l}\text { - Non-blinded, non-randomised and uncontrolled trial. } \\
\text { - Less than } 6 \text { months study duration. } \\
\text { - No seizure-free dogs. } \\
\text { - Tier I confidence level for diagnosing idiopathic epilepsy for } \\
\end{array} \quad$ some cases \\
\hline
\end{tabular}

* The level of confidence for diagnosing idiopathic epilepsy (Tier I-III) used in this knowledge summary was based on the international veterinary epilepsy task force (IVETF) consensus statement on the diagnosis of idiopathic epilepsy (De Risio, L. et al. 2015). Any paper that included dogs with idiopathic epilepsy for which diagnostic investigations were below this Tier level of evidence or unclear was considered to provide insufficient level of confidence for diagnosing idiopathic epilepsy. Tier I was listed in the limitations of the papers as this could indicate that a few dogs might have suffered from structured epilepsy and as a result have not responded adequately or at all to the treatment.

\section{Appraisal, application and reflection}

Various antiepileptic drugs (AEDs) are used for the management of canine idiopathic epilepsy. Charalambous et al. (2014) performed a systematic review and suggested that the evidence-base in therapy of canine epilepsy is still unsatisfactory for some AEDs. Only four blinded randomized clinical trials (bRCTs) were reported which were considered to offer the highest quality of evidence amongst all the studies evaluated. The most recent one was performed by Rundfeldt et al. (2015) who compared imepitoin high ( $30 \mathrm{mg} / \mathrm{kg}$ BID) to low (1 mg/kg BID) doses and concluded that doses of $30 \mathrm{mg} / \mathrm{kg}$ BID are effective in managing seizures in dogs with idiopathic epilepsy. Apart from these bRCTs, the majority of the evidence derived from non-blinded, non-randomised, uncontrolled clinical trials and case series. The studies included in this summary and the systematic review Charalambous et al. (2014) suggested that oral phenobarbital and imepitoin in particular, as well as potassium bromide and levetiracetam are likely to be effective for the treatment of idiopathic epilepsy. Precisely, a good level of evidence supported the efficacy of oral phenobarbital and imepitoin as monotherapy AEDs, fair and insufficient level of evidence supported the efficacy of potassium bromide as monotherapy and adjunct AED respectively and fair level of evidence supported the efficacy of levetiracetam as adjunct AED. Levetiracetam can be also used effectively as pulse therapy against cluster seizures according to a recent report by Packer, Nye et al. (2015). For the remaining AEDs (i.e. zonisamide, primidone, gabapentin, pregabalin, sodium valproate, felbamate, topiramate) favorable results were reported regarding their efficacy, but there was insufficient evidence to support their use mainly due to lack of bRCTs.

Although individual assumptions for AEDs' efficacy could be made based on the studies' results and the level of evidence provided, direct comparisons of efficacy between AEDs were limited due to lack of controlled studies. Precisely, based on the controlled studies, direct AED comparisons include:

\section{Phenobarbital vs Imepitoin}

Tipold et al. (2014) showed that monotherapy with imepitoin in dogs with newly diagnosed epilepsy was almost similarly effective and potentially more tolerated than phenobarbital. The same result was reported within other studies investigated in the systematic review by Charalambous et al. (2014).

\section{Phenobarbital vs Potassium bromide}

Bootheet al. (2012) and Gaskill and Kimber (2010) found that phenobarbital was more effective and better tolerated than potassium bromide monotherapy. 


\section{Phenobarbital vs Primidone}

Schwartz-Porsche et al. (1985) reported that the difference between the efficacy of phenobarbital and primidone was not significant, but primidone caused signs of liver toxicity in $70 \%$ of the dogs in the group.

\section{Primidone vs Imepitoin}

In a US field study, as reported in the EMEA (2012) report, imepitoin failed to demonstrate higher efficacy compared to primidone. However, this study was considered only as supportive information because the control group therapy (primidone) is not approved in Europe.

Finally, Muñana et al. (2012) compared levetiracetam to placebo and found that seizure frequency was reduced significantly compared to baseline but no difference was detected when compared to the placebo group. Direct comparisons between other AEDs could not be performed based on the current published evidence. Generally, AED monotherapy or adjunctive therapy with multiple drugs can be chosen according to the clinically successful control of seizures (i.e. usually $>50 \%$ or, ideally, $100 \%$ reduction in seizure frequency) and side effects. Freds $\varnothing$ et al. (2014) reported that in dogs where monotherapy was not sufficient, the need for treatment with two AEDs has not been linked to a reduced survival. Packer et al. (2015) demonstrated that $37.5 \%$ of dogs that received a third-line AED after treatment failure with two AEDs were responsive to this drug (achieving $>50 \%$ reduction in seizure frequency). The same study found that only dogs that responded to the first AED became seizure-free. Lastly, Packer et al. (2014) found that the presence of cluster seizures and thus seizure density is a more influential risk factor on the likelihood of achieving remission in canine epilepsy than seizure frequency or the total number of seizures prior to treatment.

Alternative therapies have been also investigated for treating canine epilepsy (including diet trials, nerve stimulation, homeopathic agents), but the results were not very encouraging based on these. Munana et al. (2002) tried vagal nerve stimulation but the mean decrease in seizure frequency was approximately $34.4 \%$. Varshney (2007) administered belladona and cocculus, which appeared to prevent further seizures, but in a few dogs these restarted once the agents were stopped. Patterson et al. (2005) tried ketogenic food to control seizures but included only 6 dogs (considerably less than the number that was initially estimated by power calculations). The results from the last two studies were considered controversial. Matthews et al. (2012) compared fatty acid supplementation to placebo but no differences in median seizure frequency or severity were detected between the two groups. Scorza et al. (2009) reported that the administration of fish oil at 2 $\mathrm{g} / \mathrm{d}$ to a 2 year old female Great Dane successfully decreased the frequency of epileptic seizures. However, details on the type of fish oil used or specific concentrations were not reported. In a recent blinded randomised placebo-controlled cross-over trial, Law et al. (2015) compared a ketogenic medium-chain TAG diet (MCTD) with a standardised placebo diet in chronically antiepileptic drug-treated dogs with idiopathic epilepsy and showed that ketogenic diets can have antiepileptic properties translated as reduction in seizure activities.

Jambroszyk et al. (2011) investigated verapamil as an adjunct to phenobarbital but even the maximum tolerated dose failed to improve seizure control in dogs. O'Brien et al. (1997) investigated nimodipine as an adjunct to phenobarbital or primidone but the results of the study did not support its use.

At this point it is worth mentioning that the international veterinary epilepsy task force (IVETF) recently published a consensus statement (Bhatti et al. 2015) for treatment suggestions based mainly on current published evidence as provided and analyzed in this knowledge summary and in the systematic review by Charalambous et al. (2014) and it was additionally supported and adjusted by expert's opinions.

Implications for the future: Generally, several potential sources of bias and limitations were identified in the studies. Many of the studies included dogs with poor or unclear diagnostic investigations for idiopathic epilepsy and small study population and, consequently, definite recommendations are precluded. Therefore, further bRCTs are needed mainly for the AEDs, such as zonisamide, for which there are no high quality studies 
to support their favourable efficacy. Lastly, further and stronger evidence is vital for imepitoin as a new licensed drug in Europe before definite recommendation on its efficacy and tolerability are drawn.

Limitation of the summary: The main limitation of this summary is that we could not obtain full access to a few papers included in the summary of evidence. These included: Srivastava M. et al. (2013), Kis, I. et al. (2012), Musteata, M. et al. (2007), Patterson. E. et al. (2005), Steinberg, M. (2004), Cunningham, G. et al. (1983)

\section{Methodology Section}

\begin{tabular}{|r|l|}
\hline Search Strategy & \\
\hline $\begin{aligned} \text { Databases searched and dates } \\
\text { covered: }\end{aligned}$ & $\begin{array}{l}\text { PubMed and CAB Abstracts 1973 to 2015 combined search on OVID } \\
\text { platform }\end{array}$ \\
\hline Search terms: & $\begin{array}{l}\text { (dog or dogs or puppy or puppies or canis or canine) AND (idiopath*) } \\
\text { AND (epilep* or seizur* or convuls*) AND (treat* or manag* or } \\
\text { guideline* or guidance or principle* or recommend*) }\end{array}$ \\
\hline Dates searches performed: & $23 / 11 / 15$ \\
\hline
\end{tabular}

Exclusion: Summary updates, Non-systematic reviews*

Inclusion: Studies evaluating or reporting the treatment, management and diagnosis of canine idiopathic epilepsy

*There was one non-systematic review, Packer et al. (2014) that was included because it made important conclusions and valuable up-to-date points for our summary. The same paper was not included in the table though but in the text. The same applies for the IVETF consensus statements by Bhatti et al. (2015) and De Risio et al. (2015).

\begin{tabular}{|c|c|c|c|c|}
\hline \multicolumn{5}{|c|}{ Search Outcome } \\
\hline $\begin{array}{c}\text { Total number of } \\
\text { papers retrieved } \\
\text { from Pubmed and } \\
\text { CAB Abstracts }\end{array}$ & $\begin{array}{c}\text { Number of } \\
\text { duplicates } \\
\text { excluded }\end{array}$ & $\begin{array}{c}\text { Number excluded } \\
\text { due to study } \\
\text { design }\end{array}$ & $\begin{array}{c}\text { Number excluded } \\
\text { as did not satisfy } \\
\text { inclusion criteria }\end{array}$ & $\begin{array}{c}\text { Total relevant } \\
\text { papers }\end{array}$ \\
\hline 165 & 96 & 11 & 15 & 43 \\
\hline
\end{tabular}


1. Bhatti, S. F. et al. (2015) International Veterinary Epilepsy Task Force consensus proposal: medical treatment of canine epilepsy in Europe. BMC Veterinary Research, 11:176 http://dx.doi.org/10.1186/s12917-015-0464-z

2. Boothe, D.M., Dewey, C. and Carpenter, D.M. (2012) Comparison of phenobarbital with bromide as a first-choice antiepileptic drug for treatment of epilepsy in dogs. Journal of the American Veterinary Medical Association, 240 (9), pp. 1073-1083 http://dx.doi.org/10.2460/javma.240.9.1073

3. Charalambous, M., Brodbelt, D., \& Volk, H. A. (2014). Treatment in canine epilepsy-a systematic review. BMC Veterinary Research, 10:257 http://dx.doi.org/10.1186/s12917-014-0257-9

4. Chung, J.Y., et al. (2012) Zonisamide monotherapy for idiopathic epilepsy in dogs. New Zealand Veterinary Journal, 60 (6), pp. 357-359 http://dx.doi.org/10.1080/00480169.2012.680855

5. Cunningham, J.G., Haidukewych, D., Jensen, H.A. (1983) Therapeutic serum concentrations of primidone and its metabolites, phenobarbital and phenylethylmalonamide in epileptic dogs. Journal of the American Veterinary Medical Association, 182 (10), pp. 1091-1094

6. De Risio, L.,et al. (2015) International veterinary epilepsy task force consensus proposal: diagnostic approach to epilepsy in dogs. BMC Veterinary Research, 11:148. http://dx.doi.org/10.1186/s12917$\underline{015-0462-1}$

7. Dewey, C.W., et al. (2009) Pregabalin as an adjunct to phenobarbital, potassium bromide, or a combination of phenobarbital and potassium bromide for treatment of dogs with suspected idiopathic epilepsy. Journal of the American Veterinary Medical Association, 235 (12), pp. 1442-1449 http://dx.doi.org/10.2460/javma.235.12.1442

8. Dewey C.W. et al. (2004) Zonisamide therapy for refractory idiopathic epilepsy in dogs. Journal of the American Animal Hospital Association, 40 (4), pp. 285-291 http://dx.doi.org/10.5326/0400285

9. European Medicines Agency (2012) CVMP assessment report for Pexion (EMEA/V/C/002543/0000). London: EMEA

10. Freds $\varnothing$, N. et al. (2014) Risk factors for survival in a university hospital population of dogs with epilepsy. Journal of Veterinary Internal Medicine 28 (6), pp. 1782-1788 http://dx.doi.org/10.1111/ivim.12443

11. Gaskill, C.L. and Kimber, W.J. (2010) Comparison of phenobarbital and potassium bromide monotherapies in the treatment of canine epilepsy. Journal of Veterinary Internal Medicine, 24 (3), pp. 696

12. Govendir, M., Perkins, M. and Malik, R. (2005) Improving seizure control in dogs with refractory epilepsy using gabapentin as an adjunctive agent. Australian Veterinary Journal, 83 (10) pp. 602-608 http://dx.doi.org/10.1111/j.1751-0813.2005.tb13269.x

13. Heynold, Y.et al. (1997) Clinical, epidemiological and treatment results of idiopathic epilepsy in 54 labrador retrievers: a long-term study. The Journal of Small Animal Practice, 38 (1), pp. 7-14 http://dx.doi.org/10.1111/j.1748-5827.1997.tb02977.x

14. Jambroszyk, M., Tipold, A. and Potschka, H. (2011) Add-on treatment with verapamil in pharmacoresistant canine epilepsy. Epilepsia, 52 (2), pp. 284-291 http://dx.doi.org/10.1111/i.15281167.2010.02886.x

15. Kis, I. et al. (2012) The concentration of phenobarbital in dogs with idiopathic epilepsy in Croatia. In: Peti Hrvatski Veterinarski Kongres s Meunarodnim Sudjelovanjem (5th Croatian Veterinary Congress), Tuheljske Toplice, Croatia, 10-13 October, pp. 397-403. 
16. Kiviranta, A.-M. et al. (2013) Topiramate as an add-on antiepileptic drug in treating refractory canine idiopathic epilepsy. Journal of Small Animal Practice, 54 (10), pp. 512-520.

http://dx.doi.org/10.1111/jsap.12130

17. Law, T. H. et al. (2015) A randomised trial of a medium-chain TAG diet as treatment for dogs with idiopathic epilepsy. British Journal of Nutrition, 114 (09), pp. 1438-1447

http://dx.doi.org/10.1017/S000711451500313X

18. Loscher, W. et al. (2004) Anticonvulsant efficacy of the low-affinity partial benzodiazepine receptor agonist ELB 138 in a dog seizure model and in epileptic dogs with spontaneously recurrent seizures. Epilepsia, 45 (10), pp. 1228-1239 http://dx.doi.org/10.1111/i.0013-9580.2004.21204.x

19. Matthews, H. et al. (2012) Effects of essential fatty acid supplementation in dogs with idiopathic epilepsy: a clinical trial. Veterinary Journal, 191 (3), pp. 396-398 http://dx.doi.org/10.1016/i.tvil.2011.04.018

20. Morton, D.J. and Honhold, N. (1988) Effectiveness of a therapeutic drug monitoring service as an aid to the control of canine seizures. Veterinary Record, 122(15), pp. 346-349

http://dx.doi.org/10.1136/vr.122.15.346

21. Munana, K.R. et al (2012) Evaluation of levetiracetam as adjunctive treatment for refractory canine epilepsy: a randomized, placebo-controlled, crossover trial. Journal of Veterinary Internal Medicine 26 (2), pp. 341-348 http://dx.doi.org/10.1111/j.1939-1676.2011.00866.x

22. Muñana, K. R. et al (2002) Use of vagal nerve stimulation as a treatment for refractory epilepsy in dogs. Journal of the American Veterinary Medical Association, 221 (7), pp. 977-983 http://dx.doi.org/10.2460/javma.2002.221.977

23. Musteata, M., Hagiu, N. and Ghe, S. (2007) Therapeutic efficiency of the gabapentin-phenobarbital medication in refractory idiopathic epilepsy in dog. Medicina Veterinara, 51, pp. 352-357

24. Nafe, L.A. and Kay, W. J. (1981) Sodium valproate: a preliminary clinical trial in epileptic dogs. Journal of the American Animal Hospital Association, 17 (1), pp. 131-133

25. O'Brien, D.P.et al. (1997) Nimodipine for treatment of idiopathic epilepsy in dogs. Journal of the American Veterinary Medical Association, 210 (9), pp. 1298-1301

26. Packer, R.M.A. et al (2015a) Assessment into the usage of levetiracetam usage in canine epilepsy. BMC Veterinary Research, 11 (25) http://dx.doi.org/10.1186/s12917-015-0340-x

27. Packer, R. M. A. et al. (2015b) Responses to successive anti-epileptic drugs in canine idiopathic epilepsy. Veterinary Record, 176 (8), pp. 203-205. http://dx.doi.org/10.1136/vr.102934

28. Packer, R. M. A., Shihab, N. K., Torres, B. B. J., \& Volk, H. A. (2014) Clinical risk factors associated with anti-epileptic drug responsiveness in canine epilepsy. PLOS ONE, 9(8)

http://dx.doi.org/10.1371/journal.pone.0106026

29. Patterson, E.E. et al. (2005) Results of a ketogenic food trial for dogs with idiopathic epilepsy. Journal of Veterinary Internal Medicine, 19 (3) p. 421 http://dx.doi.org/10.1111/i.19391676.2005.tb00640.x

30. Pearce, L. K. (1990) Potassium bromide as an adjunct to Phenobarbital for the management of uncontrolled seizures in dogs. Progress in Veterinary Neurology, 1, pp. 95-101

31. Platt, S. R. et al. (2006) Treatment with gabapentin of 11 dogs with refractory idiopathic epilepsy. Veterinary Record, 159 (26), pp. 881-884 http://dx.doi.org/0.1136/vr.159.26.881

32. Podell, M. and Fenner, W.R. (1993) Bromide therapy in refractory canine idiopathic epilepsy. Journal of Veterinary Internal Medicine 7 (5), pp. 318-327 http://dx.doi.org/10.1111/i.1939-1676.1993.tb01025.x

33. Rieck, S., Rundfeldt, C. and Tipold, A. (2006) Anticonvulsant activity and tolerance of ELB138 in dogs with epilepsy: a clinical pilot study. Veterinary Journal, 172 (1), pp. 86-95

http://dx.doi.org/10.1016/j.tvjl.2005.04.003 
34. Ruehlmann, D., Podell, M., March, P. (2001) Treatment of partial seizures and seizure-like activity with felbamate in six dogs. Journal of Small Animal Practice, 42 (8), pp. 403-408 http://dx.doi.org/10.1111/j.1748-5827.2001.tb02490.x

35. Rundfeldt, C., Tipold, A. and Löscher, W. (2015) Efficacy, safety, and tolerability of imepitoin in dogs with newly diagnosed epilepsy in a randomized controlled clinical study with long-term follow up. $B M C$ Veterinary Research, 11: 228 http://dx.doi.org/10.1186/s12917-015-0548-9

36. Schwartz-Porsche, D. J. U. (1991) Wirksamkeit von Bromid bei den therapieresistenten Epilepsien des Hundes. Tierarztliche Praxis, 19 (4), pp. 395-401

37. Schwartz-Porsche, D., Loscher, W. and Frey, H. H. (1982) Treatment of canine epilepsy with primidone. Journal of the American Veterinary Medical Association, 181 (6), pp. 592-595

38. Schwartz-Porsche, D., Loscher, W. and Frey, H.H. (1985) Therapeutic efficacy of phenobarbital and primidone in canine epilepsy: a comparison. Journal of Veterinary Pharmacology and Therapeutics, 8 (2). pp. 113-119 http://dx.doi.org/10.1111/i.1365-2885.1985.tb00934.x

39. Scorza, F. A. et al. (2009) Positive impact of omega-3 fatty acid supplementation in a dog with drugresistant epilepsy: a case study. Epilepsy \& Behavior, 15 (4), pp. 527-528 http://dx.doi.org/10.1016/j.yebeh.2009.05.013

40. Srivastava, M., Singh, N. K. and Srivastava, A. (2013) Management of Phenobarbital Refractory Idiopathic Epilepsy by Potassium Bromide in Dogs. Advances in Animal and Veterinary Sciences, 1 (1), pp. 25-27

41. Steinberg, M.F.D. (2004) Levetiracetam therapy for long-term idiopathic epileptic dogs. ACVIM Abstracts. Journal of Veterinary Internal Medicine, 18 (3), p. 410

42. Tipold, A. et al. (2015) Clinical efficacy and safety of imepitoin in comparison with phenobarbital for the control of idiopathic epilepsy in dogs. Journal of Veterinary Pharmacology and Therapeutics 38 (2), pp. 160-168 http://dx.doi.org/10.1111/ivp.12151

43. Trepanier, L.A. et al (1998) Therapeutic serum drug concentrations in epileptic dogs treated with potassium bromide alone or in combination with other anticonvulsants: 122 cases (1992-1996). Journal of the American Veterinary Medical Association, 213 (10), pp. 1449-1453

44. Varshney, J. P. (2007) Clinical management of idiopathic epilepsy in dogs with homeopathic $<$ i> Belladonna 200C: a case series. Homeopathy, 96 (1), pp. 46-48 http://dx.doi.org/10.1016/j.homp.2006.09.002

45. Volk, H.A. et al (2008) The efficacy and tolerability of levetiracetam in pharmacoresistant epileptic dogs. Veterinary Journal, 2008, 176 (3), pp.310-319 http://dx.doi.org/10.1016/j.tvjl.2007.03.002

46. Von Klopmann, T., Rambeck, B. and Tipold, A. (2007) Prospective study of zonisamide therapy for refractory idiopathic epilepsy in dogs. Journal of Small Animal Practice, 48 (3), pp. 134-138 http://dx.doi.org/10.1111/j.1748-5827.2006.00290. 


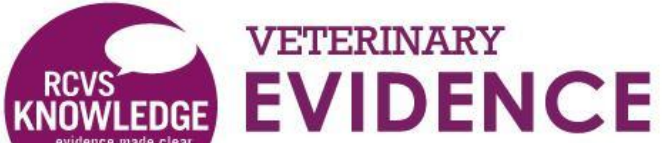 \\ orthe}

\section{Intellectual Property Rights}

Authors of Knowledge Summaries submitted to RCVS Knowledge for publication will retain copyright in their work, but will be required to grant to RCVS Knowledge an exclusive license of the rights of copyright in the materials including but not limited to the right to publish, re-publish, transmit, sell, distribute and otherwise use the materials in all languages and all media throughout the world, and to license or permit others to do so.

Authors will be required to complete a license for publication form, and will in return retain certain rights as detailed on the form.

Veterinary Evidence and EBVM Network are RCVS Knowledge initiatives. For more information please contact us at editor@veterinaryevidence.org.

RCVS Knowledge is the independent charity associated with the Royal College of Veterinary Surgeons (RCVS). Our ambition is to become a global intermediary for evidence based veterinary knowledge by providing access to information that is of immediate value to practicing veterinary professionals and directly contributes to evidence based clinical decision-making.

\section{www.veterinaryevidence.org}

RCVS Knowledge is a registered Charity No. 230886. Registered as a Company limited by guarantee in England and Wales No. 598443.

Registered Office:

Belgravia House

62-64 Horseferry Road

London SW1P 2AF 